\title{
Stratigraphy and development of c. 17000 year old Lake Maratoto, North Island, New Zealand, with some inferences about postglacial climatic change
}

\author{
J. D. GREEN \\ D. J. LOWE \\ School of Science \\ University of Waikato \\ Private Bag \\ Hamilton, New Zealand
}

\begin{abstract}
The stratigraphy and geomorphology of Lake Maratoto and its surrounds were investigated as part of a programme of paleolimnological studies based on sediment cores from lakes in northern North Island. Changes in the lake and catchment were inferred from variations in sediment character, the correlation and timing being determined from distinctive tephra layers in the sediments and by radiocarbon dating. Nineteen new C-14 dates, on gyttja or peat, are reported (old $T^{1 / 2}$, years B.P.): 11 on tephras (Mamaku Ash $6830+$ 90, Wk227; Rotoma Ash $8370 \pm 90$, Wk522; $83 \overline{50}$ \pm 100, Wk523; Opepe Tephra $9370 \pm 210$, Wk230; Mangamate Tephra $9700 \pm 140, \overline{\mathrm{W}} \mathrm{k} 231 ; 10000$ \pm 120, Wk232; Waiohau Ash $12200 \pm 230$, Wk233; $12500 \pm 190, W k 234 ; 12450 \pm 200$, Wk515; $12300+190$, Wk516; Rotorua Ash 13450 \pm 120, Wk511); 5 on the deposition of Hinuera Formation alluvium $(16300 \pm 250$, Wk239; 16900 \pm 470, Wk240; $17050 \pm 200, W k 358 ; 16200$ +360-340, Wk509; $15850+130$, Wk510); and 3 on basal peat of the Rukuhia bog (10250 \pm 90 , Wk114; $15200 \pm 130, W k 534 ; 10600 \pm 90$, Wk553).
\end{abstract}

Lake Maratoto originated c. 17000 years ago when a small valley was dammed by volcanogenic alluvium (Hinuera Formation). From c. 17000 to c. 14000 years ago the lake was about $2 \mathrm{~m}$ deep with clear water. Marginal peat first developed at c. 15000 years ago, reducing the area of the lake by about one-half by c. 13000 years ago. Lake area then expanded, possibly because of marginal erosion and/or oxidation of the peat, to its maximum size at the present day. The adjacent Rukuhia peat bog grew rapidly from c. 11000 years ago and is now $8 \mathrm{~m}$ thick immediately to the west of the lake. As a result of this growth, the lake became dystrophic and deepened $(3.5 \mathrm{~m}$ at c. 7000 years ago, $6.4 \mathrm{~m}$ at c. 2000 years ago, and $7.1 \mathrm{~m}$ today).

Received 25 June 1984, accepted 22 July 1985
The developmental history suggests that net precipitation increased at c. 15000 years ago, increased further at c. 11000 years ago, remaining high to c. 7000 years ago at least, but with a decline at or before c. 2000 years ago. There may have been a distinctly wetter or windier period from c. 10000 to 9000 years ago.

This interpretation is consistent with other reconstructions of postglacial climate in the Southern Hemisphere.

Keywords paleolimnology; lake sediments; drainage basins; peat; pyroclastics; tephrostratigraphy; tephrochronology; C-14; absolute age; ferromagnesian mineralogy; glass chemistry; late Quaternary; Holocene; climate; lake-level fluctuations; Hamilton Basin; Hinuera Formation; Lake Maratoto; Rukuhia; bogs

\section{INTRODUCTION}

Paleolimnology is a useful discipline for the investigation of Quaternary paleoecology and paleoclimate (e.g., Frey 1969; Birks \& Birks 1980; Pennington 1981; Binford et al. 1983; Brugam 1984). Few such studies, none comprehensive, have been done in New Zealand (e.g., Deevey 1955; Kennedy et al. 1978; Boubée 1983; McGlone 1983), and hence we have begun a programme of paleolimnological studies based on sediment cores from lakes in the northern North Island.

One of the most promising areas for these studies is the Hamilton Basin (Fig. 1). Its major geomorphological features were developed in the late Quaternary, mainly by aggradation of the ancestral Waikato River (McCraw 1967; Hume et al. 1975), when a number of peat bogs and small lakes were formed. Exploratory corings of sediments on some of the lakes in 1979 verified that they are ideal sites for paleolimnological studies. The lakes are shallow with soft sediments and very low sedimentation rates. Particularly notable is a series of laterally continuous, thin, distinct volcanic ash layers. The stratigraphic sequence, thickness, lithology, and bedding characteristics of these layers is practically identical in all of the lakes examined, hence they are regarded as primary tephras (Lowe et al. 1980) and of great value as time-stratigraphic markers. Lake Maratoto, located about $10 \mathrm{~km}$ south of Hamilton City (Fig. 1), was chosen as the site 


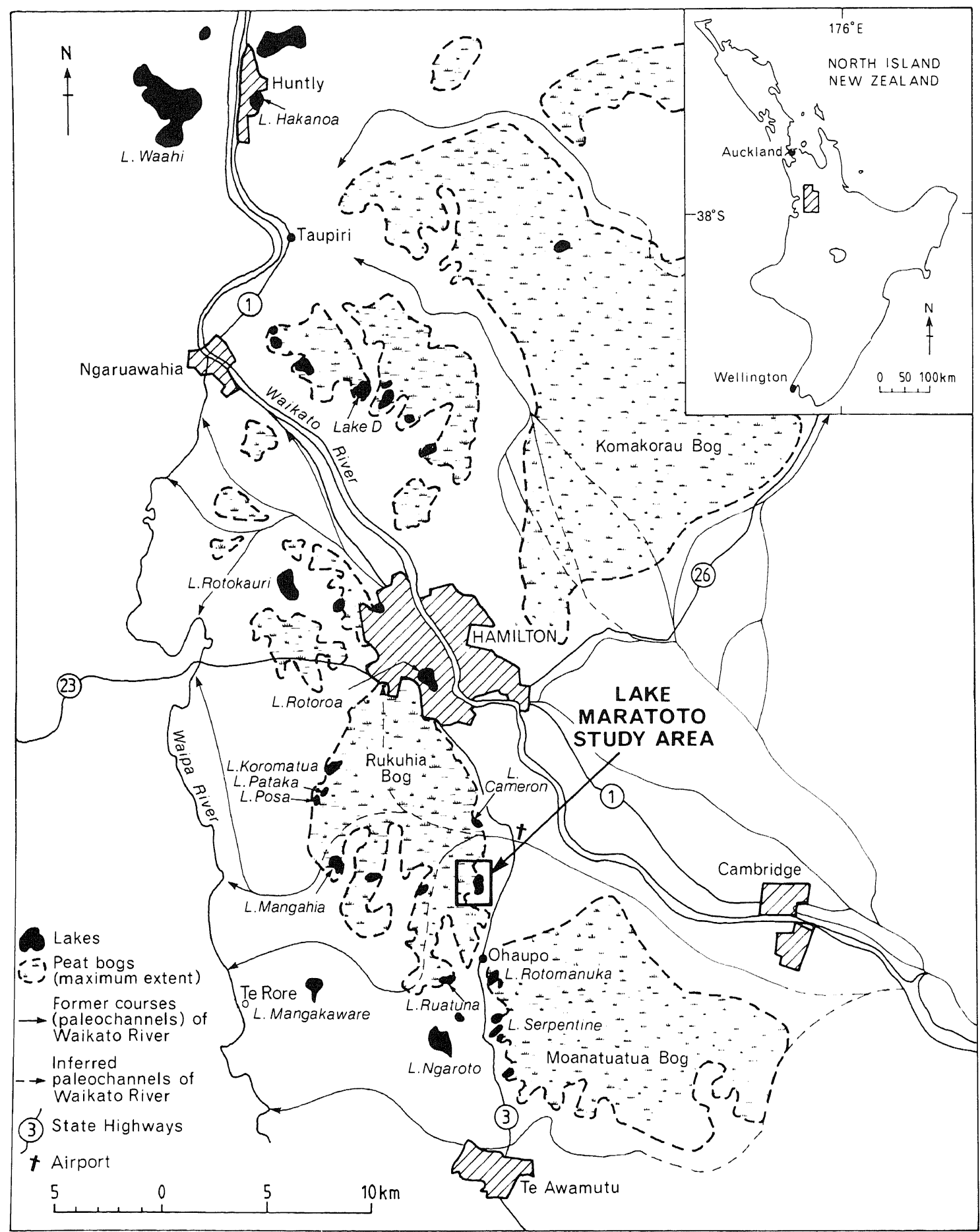

Fig. 1 The Hamilton Basin showing the location of Lake Maratoto and the distribution of other Waikato lakes, peat bogs, and the latest paleochannels of the Waikato River (after McCraw 1967). 


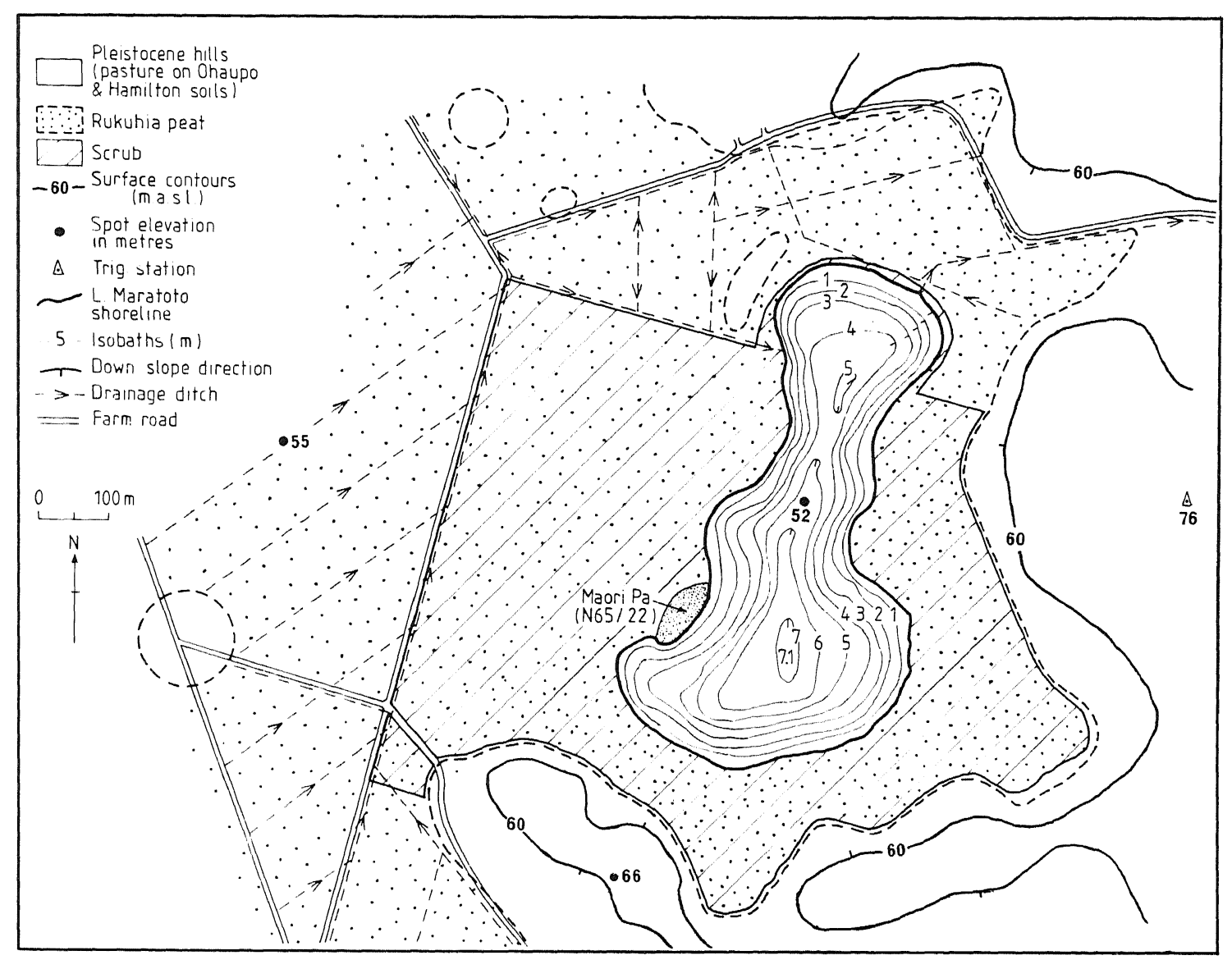

Fig. 2 The present-day Lake Maratoto area. The bathymetry is from Irwin (1982). The drainage ditches are modern, the lake having no outlet in pre-European times.

for initial paleolimnological studies. The purpose of this paper is to establish the age, origin, and developmental history of the lake basin.

Previous accounts of the origins of the lakes in the Hamilton Basin have been based on observations of lakes situated away from peat bogs (e.g., Lakes Rotokauri, Mangakaware, and Ngaroto; Fig. 1). Such lakes were formed when small valleys in low hills were blocked with alluvium (Hinuera Formation) deposited by the Waikato River at about the close of the last glaciation (McCraw 1967). Lakes on the margins of peat bogs, such as Lake Maratoto (and Lakes Cameron, Mangahia, Rotomanuka, and D; Fig. 1), are all situated within or near embayments in the hills, suggesting that they also lie in dammed valleys. However, this cannot be confirmed by observation of the local geomorphology as much of the older landscape in their vicinity is hidden by the blanket of younger peat. It is con- ceivable that some of these lakes may have been formed by encroaching peat alone, backing up water draining from a valley (Grange et al. 1939). If the lakes did originate as valleys dammed by alluvium, it seems likely that later peat accumulation would have contributed to the form and depth of the present lake basins.

The age of the lakes is unknown, but they could have been formed at any time since the onset of deposition of the Hinuera Formation, which occurred in two phases: Hinuera-1 sedimentation (between c. 65000 and 20000 years ago) and Hinuera-2 sedimentation (between c. 20000 and 12000 years ago) (Schofield 1965; Hume et al. 1975; McGlone et al. 1978).

We have clarified the mode of origin of Lake Maratoto (and, by implication, other peat lakes in the area) by determining the topography, composition, and age of the surface lying below the lake 


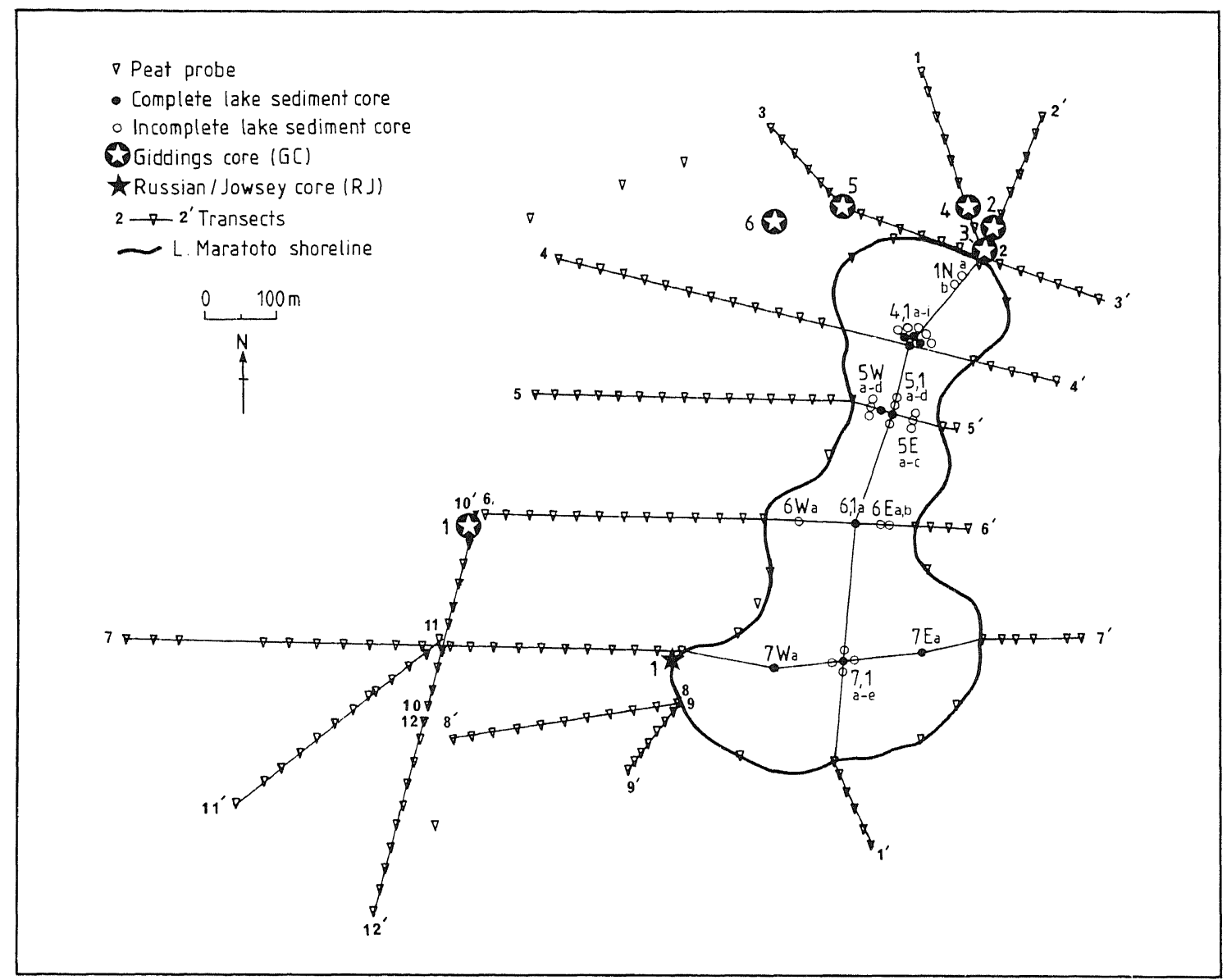

Fig. 3 Locations of transects and probing and coring sites. Lake sediment cores were labelled according to the transect they were on (a number) and their position in the lake (a letter) as follows: western cores $(5 \mathrm{~W} ; 6 \mathrm{~W} ; 7 \mathrm{~W}$ ), eastern cores $(5 \mathrm{E} ; 6 \mathrm{E} ; 7 \mathrm{E})$, north cores $(1 \mathrm{~N})$ and central cores (all on transect $\left.1-1^{\prime}\right)(4,1 ; 5,1 ; 6,1 ; 7,1)$. The first core taken at each location was designated a (e.g., $5 \mathrm{Wa}$ ), the second $\mathrm{b}(5 \mathrm{~Wb})$, and so on (see also Fig. 8 ).

sediments and surrounding peat. To find the age of the lake we have radiocarbon-dated the base of the lake sediments, and have estimated rates of sedimentation in the lake using the dated tephras in the sediments (Lowe et al. 1980). Utilising this tephrochronology, we also determined variations in the lake's area and depth, and the influence of peat development, from changes in the character of the lake sediment. The results have enabled us to make inferences about some aspects of postglacial climatic change.

\section{Lake Maratoto and its surroundings}

Lake Maratoto $\left(37^{\circ} 53^{\prime} \mathrm{S} 175^{\circ} 18^{\prime} \mathrm{E}\right)$ lies on the eastern border of the domed ombrogenous Rukuhia peat bog (23000 ha) (Fig. 1). The lake, at an elevation of $52 \mathrm{~m}$ a.s.l., occupies an embayment in low hills that rise to $76 \mathrm{~m}$ a.s. 1 . immediately to the east of the lake with lower elevations to the north and south (Fig. 2). Such low hills in the Hamilton region consist of weathered Pleistocene tephras, ignimbrites, and volcaniclastic sediments that predate deposition of the volcanogenic Hinuera Formation (Kear \& Schofield 1978). The lake is surrounded by peat, but to the west and northwest (Fig. 2) the tops of Pleistocene hills emerge above the peat, showing that the surface below is of varied relief. Some of this subpeat surface consists of Hinuera Formation sands and gravels since farm well-drilling showed "sand" 7-10 m below the present peat surface c. $400 \mathrm{~m}$ to the west of the lake (B. Davies pers. comm.). 
The lake's bathymetry is shown in Fig. 2; its surface area is $16 \mathrm{ha}$, maximum depth $7.1 \mathrm{~m}$, and volume $535100 \mathrm{~m}^{3}$.

\section{METHODS}

Depths of peat and lake sediment were determined at regular distances along a series of transects (Fig. $3)^{*}$.

Surface contours of the peat along these transects were determined by standard levelling techniques with the lake surface ( $52 \mathrm{~m}$ a.s.l) as the datum. Peat depths were measured, usually at $30 \mathrm{~m}$ intervals along the transects, with a peat probe fitted with an auger for obtaining a bottom sample. An indication of the type of substrate below the peat was obtained by (1) examining the sample in the auger screw, which sampled clays and muds, and (2) listening to sound transmitted up the probe-gravels and sands were readily identified in this way.

Lake sediment was sampled along the transects (Fig. 3) with a modified Livingstone piston corer. The coring tube was $4 \mathrm{~m}$ of $50 \mathrm{~mm}$ internal diameter PVC pipe. The lake sediment was described and classified from its colour, consistence, texture, and organic content.

*Some of these transects have also been profiled using subsurface interface radar in a separate study by Lowe (1985, this issue), evaluating the effectiveness of the radar method for this sort of work.
To positively identify substrate types noted during peat probing, seven cores were taken through the peat and into the underlying sediments (Fig. 3). Six of the cores (GC1-GC6) were taken with a Giddings motorised hydraulic drilling rig, and one (RJ1) with a modified Russian/Jowsey D-section manual corer. The particle-size distribution of substrate samples from these cores was analysed by sieve and pipette (Folk 1968), and sand-fraction (2-4申) compositions were determined by standard methods (see Table 3). Alluvial and colluvial muds and sands beneath the lake sediments were also sampled and particle-size distributions and sand-fraction compositions were similarly determined. Ashy horizons found in the peat column, and in the lake sediment cores below Rerewhakaaitu tephra (i.e., additional to the tephras described by Lowe et al. 1980), were correlated with known tephras mainly from their ferromagnesian mineralogy; the identification of one tephra (Waiohau Ash) was confirmed by electron microprobe analysis of its glass shards (see Table 2).

Sixteen samples of the lake sediment were collected to date the major tephra layers and other significant horizons in the core (e.g., the base of the lake sediment). These samples were composites of several $1 \mathrm{~cm}$ thick slices of sediment taken above and below the tephras in suitable cores from throughout the lake. The tephras, identified by Lowe et al. (1980), were correlated from core to core by their distinctive colour, thickness, lithology, and stratigraphic position. (Several of the tephra identifications of Lowe et al. (1980) were
Table 1 Dominant ferromagnesian mineral abundances* in Mamaku Ash, Rotoma Ash, and Waiohau Ash at Lake Maratoto.

\begin{tabular}{|c|c|c|c|c|c|c|c|}
\hline \multirow[b]{2}{*}{ Tephra } & \multirow[b]{2}{*}{ Sample $\dagger$} & \multicolumn{5}{|c|}{$\begin{array}{l}\text { Ferromagnesian silicate minerals } \\
\text { (summed to } 100 \% \text { ) }\end{array}$} & \multirow{2}{*}{$\begin{array}{l}\text { Opaques } \\
(\text { vol\%) }\end{array}$} \\
\hline & & Hyp & Aug & Hbe & $\mathrm{Cgt}$ & Bio & \\
\hline Mamaku Ash & $\begin{array}{l}1 \\
2\end{array}$ & $\begin{array}{l}75 \\
56\end{array}$ & $\begin{array}{r}8 \\
10\end{array}$ & $\begin{array}{l}17 \\
34\end{array}$ & $\begin{array}{r}\operatorname{tr} \\
0\end{array}$ & $\begin{array}{l}0 \\
0\end{array}$ & $\begin{array}{l}19 \\
32\end{array}$ \\
\hline Rotoma Ash & $\begin{array}{l}3 \\
4\end{array}$ & $\begin{array}{l}57 \\
49\end{array}$ & $\begin{array}{l}29 \\
27\end{array}$ & $\begin{array}{r}4 \\
11\end{array}$ & $\begin{array}{l}10 \\
13\end{array}$ & $\begin{array}{c}\operatorname{tr} \\
0\end{array}$ & $\begin{array}{r}25 \\
8\end{array}$ \\
\hline Waiohau Ash & $\begin{array}{l}5 \\
6 \\
7\end{array}$ & $\begin{array}{l}73 \\
52 \\
58\end{array}$ & $\begin{array}{r}2 \\
18 \\
7\end{array}$ & $\begin{array}{l}24 \\
27 \\
31\end{array}$ & $\begin{array}{r}0 \\
\operatorname{tr} \\
0\end{array}$ & $\begin{array}{l}1 \\
3 \\
4\end{array}$ & $\begin{array}{l}34 \\
27 \\
42\end{array}$ \\
\hline
\end{tabular}

*Determined by point-count of the 2-4\$ $(250-63 \mu \mathrm{m})$ size fraction of the heavy mineral assemblage $\left(\geqslant 2.95 \mathrm{~g} / \mathrm{cm}^{3}\right)$. Between 200 and 500 grains were counted.

$\dagger 1=$ peat core RJ $1-2 ; 2=$ Lake Maratoto core $4,1 \mathrm{~b} ; 3=$ Lake Maratoto core 4,1 b; 4 = Lake Maratoto core 4,1f; $5=$ peat core RJ 1-3; 6 = Lake Maratoto core $4,1 \mathrm{~b} ; 7=$ Lake Maratoto core 4,1d.

$\$$ Proportion of opaque minerals (mainly titanomagnetite) in $2-4 \phi$ heavy mineral fraction.

$\mathrm{Hyp}=$ hypersthene; Aug = augite; $\mathrm{Hbe}=$ calcic hornblende; $\mathrm{Cgt}=$ cummingtonite; $\mathrm{Bio}=$ biotite; $\operatorname{tr}=\operatorname{trace}(<1 \%)$ 
Table 2 Electron microprobe analyses* of glass from Mamaku Ash, Rotoma Ash, Waiohau Ash, and Rotorua Ash in peat and lake sediment cores from Lake Maratoto or Lake Rotomanuka. The analyses are presented on a normalised $100 \%$ loss free basis.

\begin{tabular}{lcccrr}
\hline & 1 & $\mathbf{2}$ & $\mathbf{3}$ & $\mathbf{4}$ & $\mathbf{5}$ \\
\hline $\mathrm{SiO}_{2}$ & $78.87(0.50)$ & $78.63(0.16)$ & $78.32(0.33)$ & $78.61(0.30)$ & $77.57(0.58)$ \\
$\mathrm{Al}_{2} \mathrm{O}_{3}$ & $12.05(0.17)$ & $12.33(0.10)$ & $12.38(0.13)$ & $12.35(0.13)$ & $12.68(0.32)$ \\
$\mathrm{TiO}_{2}$ & $0.12(0.02)$ & $0.10(0.05)$ & $0.11(0.05)$ & $0.13(0.03)$ & $0.21(0.05)$ \\
$\mathrm{FeO} \dagger$ & $0.87(0.07)$ & $0.87(0.07)$ & $0.87(0.07)$ & $0.92(0.08)$ & $1.26(0.09)$ \\
$\mathrm{MgO}$ & $0.10(0.02)$ & $0.12(0.02)$ & $0.10(0.03)$ & $0.14(0.01)$ & $0.20(0.08)$ \\
$\mathrm{CaO}$ & $0.69(0.10)$ & $0.71(0.07)$ & $0.82(0.05)$ & $0.89(0.04)$ & $1.20(0.33)$ \\
$\mathrm{Na}, \mathrm{O}$ & $3.80(0.20)$ & $3.76(0.06)$ & $3.55(0.16)$ & $3.60(0.28)$ & $3.55(0.29)$ \\
$\mathrm{K}, \mathrm{O}$ & $3.38(0.43)$ & $3.37(0.09)$ & $3.73(0.41)$ & $3.26(0.10)$ & $3.19(0.44)$ \\
$\mathrm{Cl}$ & $0.12(0.02)$ & $0.11(0.05)$ & $0.12(0.01)$ & $0.10(0.03)$ & $0.14(0.03)$ \\
Waterł & $1.13(1.40)$ & $0.70(0.43)$ & $3.05(1.58)$ & $4.99(3.00)$ & $7.07(1.71)$ \\
$\mathrm{n}$ & 14 & 10 & 11 & 10 & 10 \\
\hline
\end{tabular}

1 = Mamaku Ash (Lake Rotomanuka, core A); 2 = Rotoma Ash (Lake Rotomanuka, core C); 3 = Waiohau Ash (peat core RJ1-3, Lake Maratoto); 4 = Waiohau Ash (Lake Rotomanuka, core A); 5 = Rotorua Ash (Lake Rotomanuka, core A).

$\mathrm{n}=$ number of analyses in mean (each analysis was done on a different shard); numbers in parentheses are 1 standard deviation. The location of Lake Rotomanuka is shown in Fig. 1; cores A \& C were taken from near grid ref. (NZMS 260) S15/136615.

*Glass shards in the $2-4 \phi$ size fractions were separated and purified using heavy liquids and Frantz electromagnetic methods, embedded in epoxy resin, polished, carbon coated, and analysed with a JEOL JXA-733 SUPERPROBE at the Analytical Facility, Victoria University of Wellington (Froggatt \& Gosson 1982). All samples were analysed using an $8.0 \mathrm{nA}$ beam current with either a $10 \mu \mathrm{m}$ or $20 \mu \mathrm{m}$ beam diameter, and peak counts of $3 \times 10 \mathrm{~s}$ (meaned). Repeated analysis of glass standards (KN-1 8 comendite glass; VG-99 basaltic glass; VG-568 rhyolite glass) gave a check on probe calibration and operation. There was probably some loss of $\mathrm{Na}$ and water by volatilisation (see also Froggatt 1983). Concentrations are given in oxide weight percent except $\mathrm{Cl}$ which is in atomic weight percent. Data are from D. J. Lowe (in prep.): "Stratigraphy, chronology, and correlation of late Quaternary rhyolitic and andesitic tephras interbedded with organic lake deposits in the Waikato region, North Island, New Zealand".

$\dagger$ All Fe calculated as FeO.

\$Difference between analytical total and 100 .

provisional, and modifications based on new mineralogical and glass chemistry data (Table 1 and 2) are noted below.) Slices of peat $5 \mathrm{~cm}$ in thickness from the bottoms of cores RJ1 and GCl were also collected. The samples were submitted for C-14 dating at the University of Waikato Radiocarbon Dating Laboratory (symbol Wk). All the dates presented and discussed in this paper are conventional and are based on the old (Libby) half-life of 5568 years (Hogg 1982).

\section{STRATIGRAPHY}

\section{Peat and prepeat deposits}

To the north and northwest of the lake (transects $1-1^{\prime}, 3-3^{\prime}, 4-4^{\prime}$; Fig. 4), peat depths are relatively shallow $(1-4 \mathrm{~m})$ and the subpeat deposits consist of greenish-blue to greyish-brown, sometimes gritty, muds. Further to the west and southwest, the peat deepens to 7-8 $\mathrm{m}$ and the subpeat materials are sands and gravels with a relatively flat surface

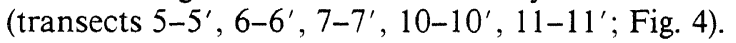

Between the lake and the hills to the east and south of the lake, the peat is less than $4 \mathrm{~m}$ thick. It shallows towards the hills and is underlain by muds similar to those beneath the peat to the north and west of the lake (transects $1-1^{\prime}, 2-2^{\prime}, 3-3^{\prime}, 4-4^{\prime}$, 5-5', 6-6', 9-9'; Fig. 4).

Core GC1 (Fig. 5) shows that the subpeat materials to the west of the lake consist of at least $5.5 \mathrm{~m}$ of Hinuera Formation and are overlain by $8 \mathrm{~m}$ of fibrous peat. The base of the peat in GCl has been dated (Wk553) at $10600 \pm 90$ years B.P. (see Fig. 9).

In core RJ1, at the southwestern lake edge, the subpeat sediments consist of a thin $(10 \mathrm{~cm})$ layer of greenish-grey mud passing down to sand of the Hinuera Formation (Fig. 5). There is more vertical variation in the texture of the peat in $\mathrm{RJ} 1$ than in $\mathrm{GCl}$, but fine lake sediment is not present. Basal peat in RJ1 has been dated (Wk534) at $15200 \pm$ 130 years B.P. Three diffuse ashy horizons, of about 10-20 mm thickness, were found in the RJ1 core. The top one (RJ1-1; Fig. 5) is identified as Taupo Pumice from its field character (vesicular, fine 
Fig. 4 Transect profiles (vertical exaggeration $\times 20$ ) produced by combining the levelled lake sediment and peat probe depths. Lake sediment thickness was taken to be the thickness of sediment plus tephra layers between the top of the consolidated lake sediment above the Taupo tephra and the junction between the muds below the Rerewhakaaitu tephra (names and stratigraphy of the tephras are given in Fig. 8). Because of its sloppy nature, some of the sediment above the Taupo tephra was occasionally not sampled or was lost during coring, and sometimes the bottom alluvial mud layer was not quite reached. In these cases, total sediment thickness was obtained by adding estimated sediment thicknesses above the Taupo tephra and below the Rerewhakaaitu tephra. These estimates were calculated from sedimentation rates in the sediment immediately above and below these tephras respectively, provided the core included all the tephras between and including the Taupo and Rerewhakaaitu. The estimates were corroborated from sediment thicknesses in more complete nearby cores.

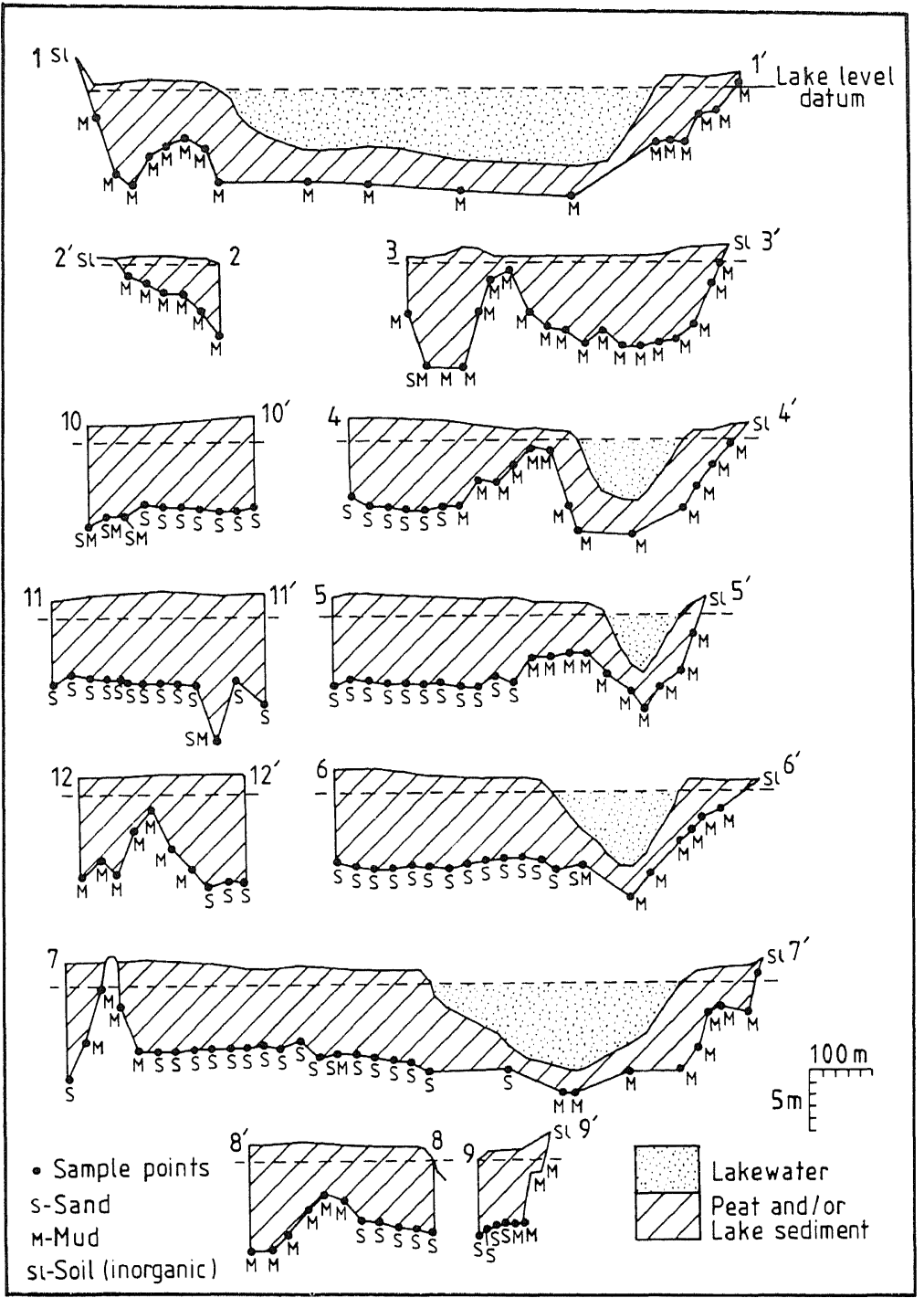

pumice lapilli) and persistent occurrence within a metre of the bog's surface. The middle (RJ1-2) and lowest (RJ1-3) ashy horizons both have a ferromagnesian mineralogy consistent with a source from the Okataina Volcanic Centre (Table 1; Lowe et al. 1980), and are probably Mamaku Ash and Waiohau Ash, respectively. The identification of the lowest tephra as Waiohau Ash was supported by the major element chemistry of its glass (Table 2). The only viable alternative, Rotorua Ash (c. 13400 years), has distinctly more $\mathrm{TiO}_{2}, \mathrm{FeO}, \mathrm{MgO}$, and $\mathrm{CaO}$ than Waiohau Ash (Fig. 6) and hence is a lesslikely correlative.
Cores GC2-5 to the north and northwest of the lake all showed similar features (Fig. 5). The peat column consists entirely of fibrous, sometimes woody, peat, occasionally with two diffuse ash layers. In GC2 these are identified as the Taupo (top) and the Mamaku tephras; in GC3 they are probably the Mamaku and Waiohau tephras. The subpeat materials consist of about $1 \mathrm{~m}$ of moderately weathered gritty mud (upper unit) unconformably overlying at least $3 \mathrm{~m}$ of stongly weathered clay (lower unit) (Fig. 5). Upper unit samples (U-1 to U-4) are texturally similar (sandy mud or sandy silt; Fig. 7A). Their grading curves (Fig. 7B) closely 

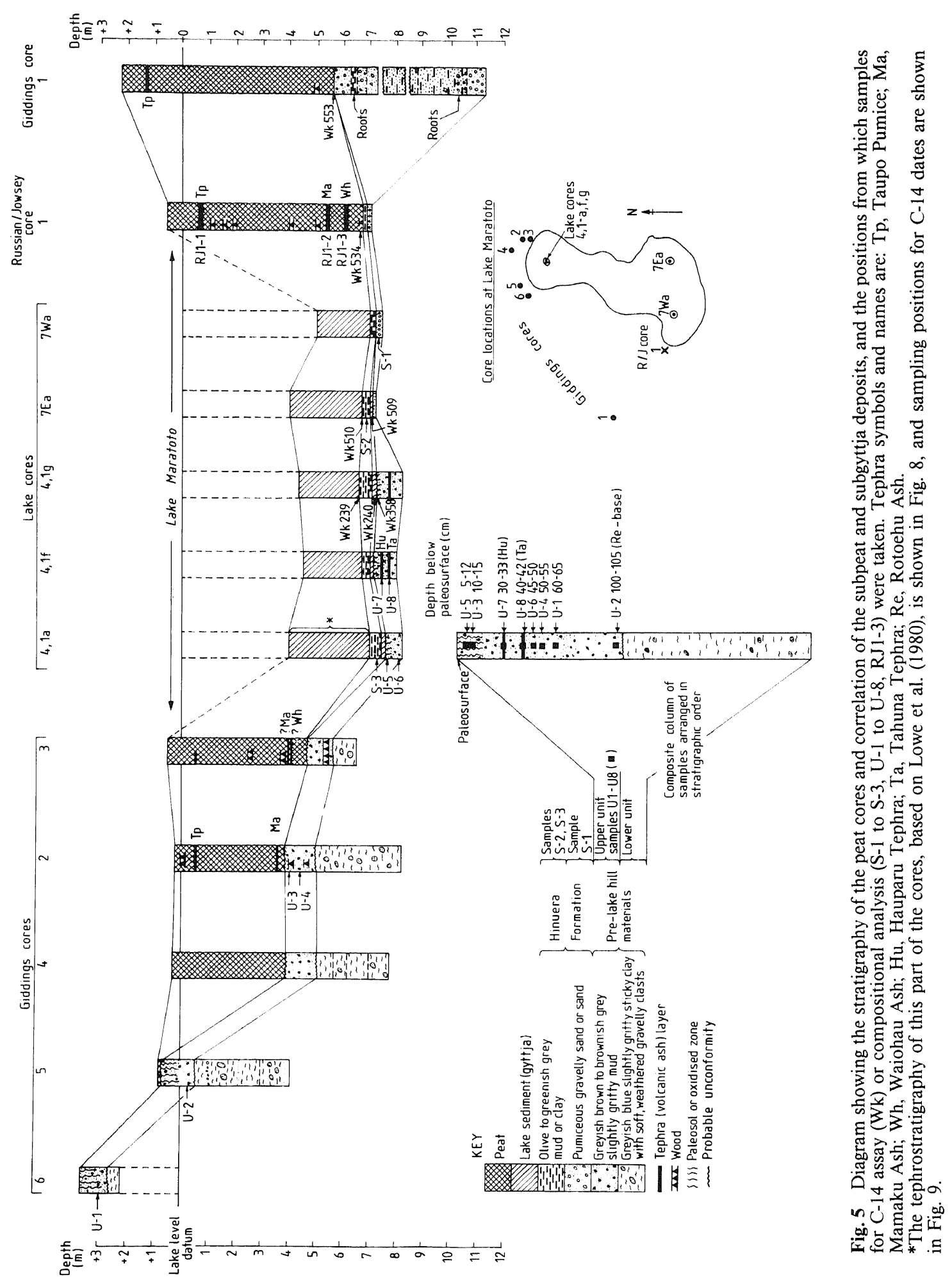

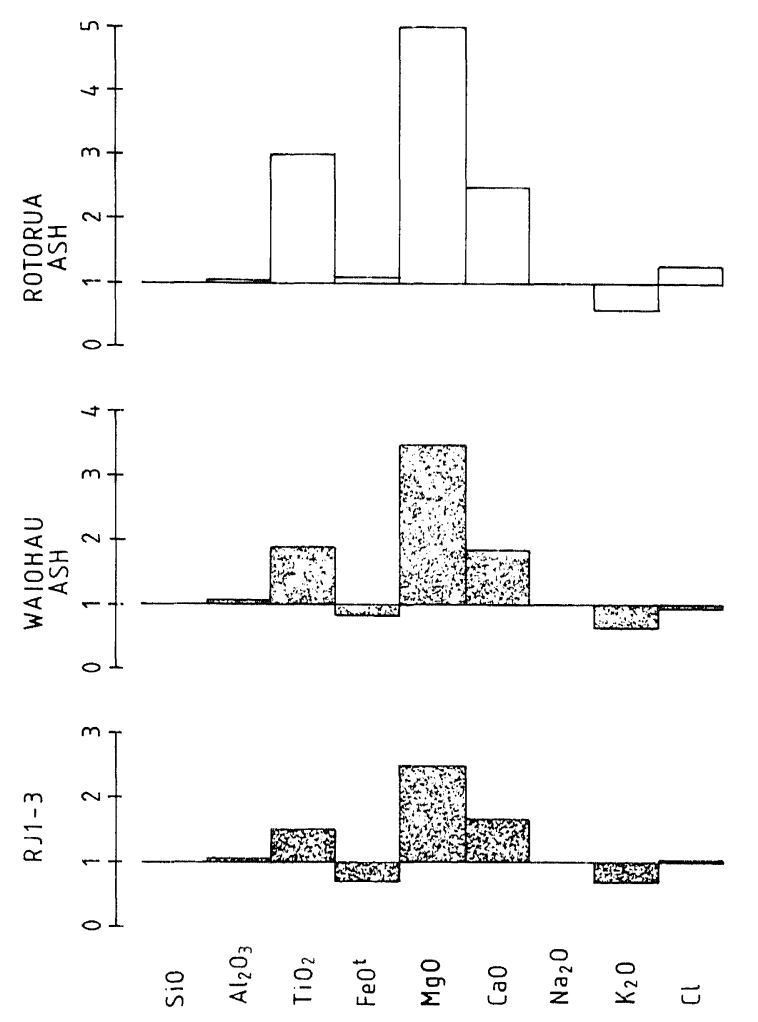

Fig. 6 Chemical composition of glass in peat core sample RJ 1-3 compared with that in samples of Waiohau Ash and Rotorua Ash (data from columns 3,4, and 5 in Table 2 , respectively). The histograms are plots of ratios of element concentrations in the samples to concentrations of the same elements in Yellowstone Rhyolite Glass standard VG-568 (the method of plotting ratios is after SarnaWojcicki et al. 1984). RJ1-3 is better matched to Waiohau Ash, its probable correlative, than to Rotorua Ash.

match those of late Pleistocene tephras that mantle the Pleistocene hills in the area. The sand mineralogical analyses (Table 3 ) confirm that the upper unit consists of late Pleistocene tephras. The top part (U-3) is probably largely derived from (?)Hauparu tephra; the middle to bottom parts (U-4, U1 , and U-2) are mainly derived from (?)Tahuna tephra mixed with Rotoehu tephra (Table 3; Fig. 7D). The lower unit consists of strongly weathered materials deposited considerably before Rotoehu tephra, hence is not considered further.

\section{Lake sediment and prelake-sediment deposits}

The stratigraphy, lithology, and chronology of the cores are given in Fig. 8. Complete cores penetrated to sublake-sediment muds and sands; other cores were incomplete but could be matched with the rest using the tephras as stratigraphic markers.

Complete cores all have an upper part consisting of 2-3 m of lake sediment (mainly dy-gyttja and gyttja, or peat in shallow-water cores) containing a series of thin (1-40 $\mathrm{mm}$ ) tephra layers, and a lower part of either about $1 \mathrm{~m}$ of olive to greenish-grey fine mud (in middle and northern cores) or up to about $50 \mathrm{~cm}$ or less of alternating greyish-white mud and unweathered pumiceous sand layers (in cores from the southwest of the lake). The junction between the gyttja and the underlying muds and sands is taken as marking the origin of the presentday lake.

Particle-size analysis (Fig. 7A, C) of three samples (S-1 to S-3) of these subgyttja materials (sand, mud, and clay, respectively) show a fining trend eastward and northward in the lake basin (evidenced also in Fig. 8). There is thus a gradation in the subpeat and subgyttja deposits from coarse gravelly sands west of the lake at $\mathrm{GC1}$, through sands at the base of RJ1 and the lake cores from the western side of the lake (cores $7 \mathrm{~W}, 6 \mathrm{~W}$ ), to muds fining to clays in the eastern and northern parts of the lake. We interpret these muds and clays as a fine lithofacies of the Hinuera Formation deposited from suspension. This view is supported by the grading curves plotted in Fig. $7 \mathrm{C}$ that show that $\mathrm{S}$ 1 is similar to Hinuera lithofacies C2 (of Hume et al. 1975), while S-2 and S-3 apparently represent a finer variant of their lithofacies $D$. The C-14 dates straddling the Hinuera muds and clays (Wk239, 510; Wk240, 509; Fig. 9) show that these were deposited relatively rapidly between c. 16000 and c. 17000 years ago. This time is around that of the last stages of vigorous Hinuera-2 deposition in the Hamilton Basin (McGlone et al. 1978).

The 10 cores that penetrated beneath the Hinuera muds or sands have a thin layer $(5-15 \mathrm{~cm})$ of olive gyttja overlying up to $80 \mathrm{~cm}$ of gritty mud, usually with a dark $20 \mathrm{~cm}$ thick paleosol-like top containing two or three diffuse grey ashy layers (Fig. 8 ). We interpret the thin gyttja layer as having been deposited in a relatively shortlived proto-Lake Maratoto (see "Developmental history").

The composition of the gritty muds (samples U-5 to U-8; Fig. 5) below the proto-Lake Maratoto gyttja matches that of the subpeat upper unit materials (Fig. 7A, B, D; Table 3). Hence they are also Pleistocene hill materials and are contiguous with the subpeat materials.

All these Pleistocene hill material samples (U-1 to U-8) thus appear to consist chiefly of Hauparu, Tahuna, and Rotoehu tephras, which are aged between c. 37000 and c. 40 000-50 000 years (Fig. 7D, 8). Neither Okareka Ash, aged between c. 17000 and c. 20000 years (Vucetich \& Pullar 1969; 


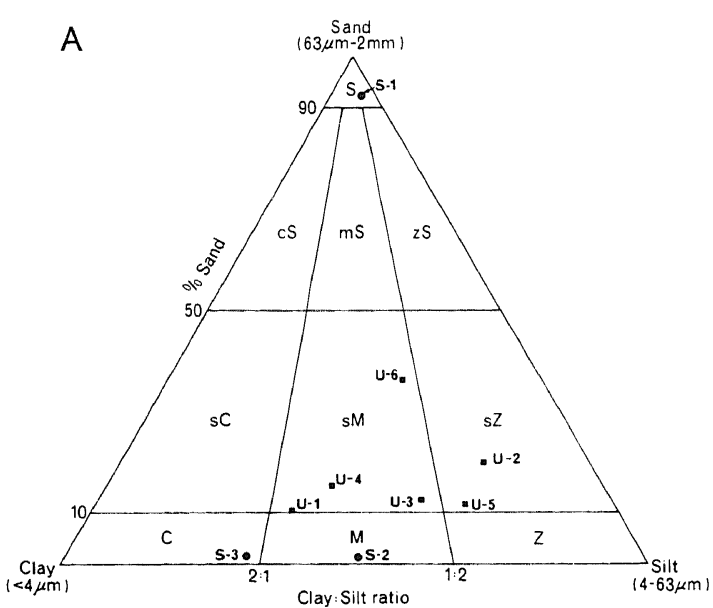

Fig. 7 Compositional analyses of the subpeat and sublake materials.

A Triangular textural plot for samples S-1 to S-3 (Hinuera Formation) and U-1 to U-6 (subpeat and subgyttja Pleistocene hill materials). Textural classes (from Folk 1968) are: S, sand; s, sandy; Z, silt; $z$, silty; M, mud; $m$, muddy; C, clay; c, clayey. Sample S-1 is a slightly gravelly sand.

Pullar et al. 1973), nor Kawakawa Tephra, aged c. 20000 years (Vucetich \& Howorth 1976a), are recognised (Table 3; Fig. 7D), although both are known to have been deposited in the region (Pullar \& Birrell 1973; Lowe 1981). So it seems that there is a disconformity, possibly of up to about 20000 years duration, between the proto-Lake Maratoto gyttja and the Pleistocene paleosurface, a suggestion supported by the moderately weathered and paleosol-like character of the paleosurface.

Lowe et al. (1980) identified the series of tephra layers above the Hinuera mud in core $4,1 \mathrm{~b}$. The tephras that were provisionally identified as ?Rotoma Ash and Unnamed ash by Lowe et al. (p. 483) are reidentified here as Mamaku Ash and Rotoma Ash, respectively. Mamaku Ash, dated at (Wk227) $6830 \pm 90$ years B.P. (Fig. 9), is characterised by its Okataina-derived ferromagnesian mineralogy (Table 1) and glass chemistry (Table 2; cf. analyses in Cole \& Nairn 1975 and Kohn 1979). Rotoma Ash, with dates of (Wk522) $8370 \pm 90$ years B.P. and (Wk523) $8350 \pm 100$ years B.P. (Fig. 9), contains the diagnostic amphibole, cummingtonite (Table 1; Hogg \& McCraw 1983). Its glass chemistry is listed in Table 2.

The Taupo, Tuhua, Mamaku, Opepe, Mangamate, Waiohau, Rotorua, and Rerewhakaaitu tephras were readily discernible in cores from throughout the lake (Fig. 8) and were used to calculate sedimentation rates during the lake's his-

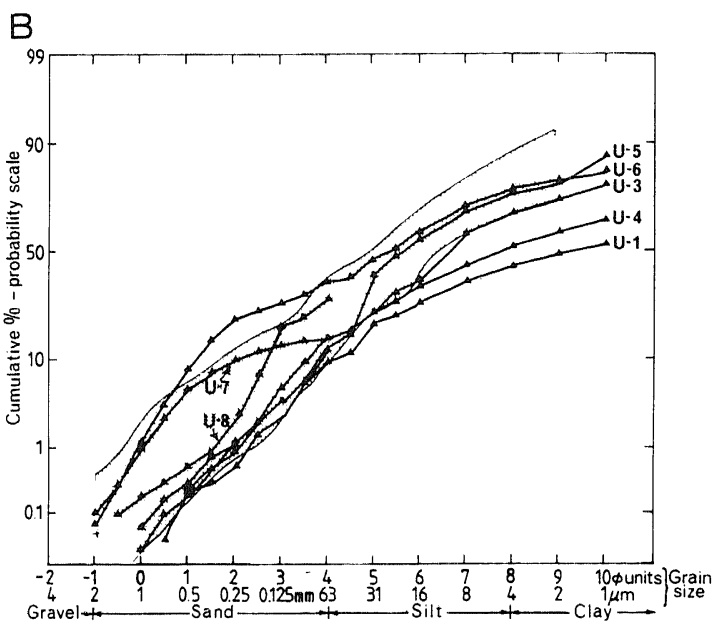

B Comparison of the particle-size distributions of upper unit materials (U-1, U-3 to U-8) with those of late Pleistocene tephras from the Waikato region (stippled band) The latter Waikato samples (30) comprise tephras aged from c. 17000 to c. $40000-50000$ years (see Table 3; data from Lowe 1981).

tory. Dates on gyttja associated with all these tephras, including 11 dates not published in Lowe et al. (1980), are given in Fig. 9. Dates on the gyttja above and below the Hinuera muds, and on the proto-Lake Maratoto gyttja, are given also.

The $\mathrm{C}-14$ dates obtained on the tephras used as markers, apart from those for the Waiohau Ash, closely match dates on the same tephras elsewhere (Topping 1973; Pullar et al. 1973; Nairn 1980; Hogg \& McCraw 1983)*. This agreement indicates that the chronology for the lake's developmental history may be regarded in large part as reliable, as the independently dated tephras provide a check on the accuracy of the radiocarbon dates (an important consideration for projected paleoecological and paleolimnological studies; Mathewes \& Westgate 1980). The Waiohau Ash has been previously dated at (NZ568) $11250 \pm 200$ years B.P., (NZ878) $11100 \pm 210$ years B.P., and (NZ1135) $11800 \pm 150$ years B.P. (Pullar \& Heine 1971) and has a generally accepted age of c. 11300 years (Pul-

*The dates obtained on Rotoma Ash (which was not used as a stratigraphic marker) differ markedly from previous age estimates of c. 7000-7300 years by Pullar \& Heine (1971) and Pullar et al. (1973), but are better matched with the date of (NZ1945) $8860 \pm 120$ years B.P. given by Nairn (1980). This latter date is significantly older than our dates, however, hence the specific age of the Rotoma Ash eruption is uncertain. 
Fig. 7 (continued).

C Particle-size distribution of subgyttja alluvial samples S- 1 to S-3. Grading curves of various lithofacies of Hinuera Formation sediments are shown for comparison (mainly after Hume et al. 1975; the majority of the unlabelled curves represent lithofacies Al or C.1).

D Ternary diagrams comparing relative abundances of ferromagnesian minerals (summed to $100 \%$, see also Table 3 ) of upper unit tephric materials (U-1 to U8 ) with those of some late Pleistocene tephras that are their possible correlatives. On this basis, the bulk of the upper unit is probably derived from Hauparu Tephra, aged c. 37000 years; Tahuna Tephra, aged c. 38000 years; and Rotoehu Ash, aged c. 4000050000 years (McGlone et al. $1984 b$; see C-14 dates in Fig. 8) In diagram $\mathrm{i}$, amphibole consists of calcic hornblende plus cummingtonite. Rotoehu Ash is characterised by a high cummingtonite content (diagram ii-Lowe 1981 Hogg \& McCraw 1983). Data sources for the mineralogies of the late Pleistocene tephras are given in note (d) of Table 3.

C
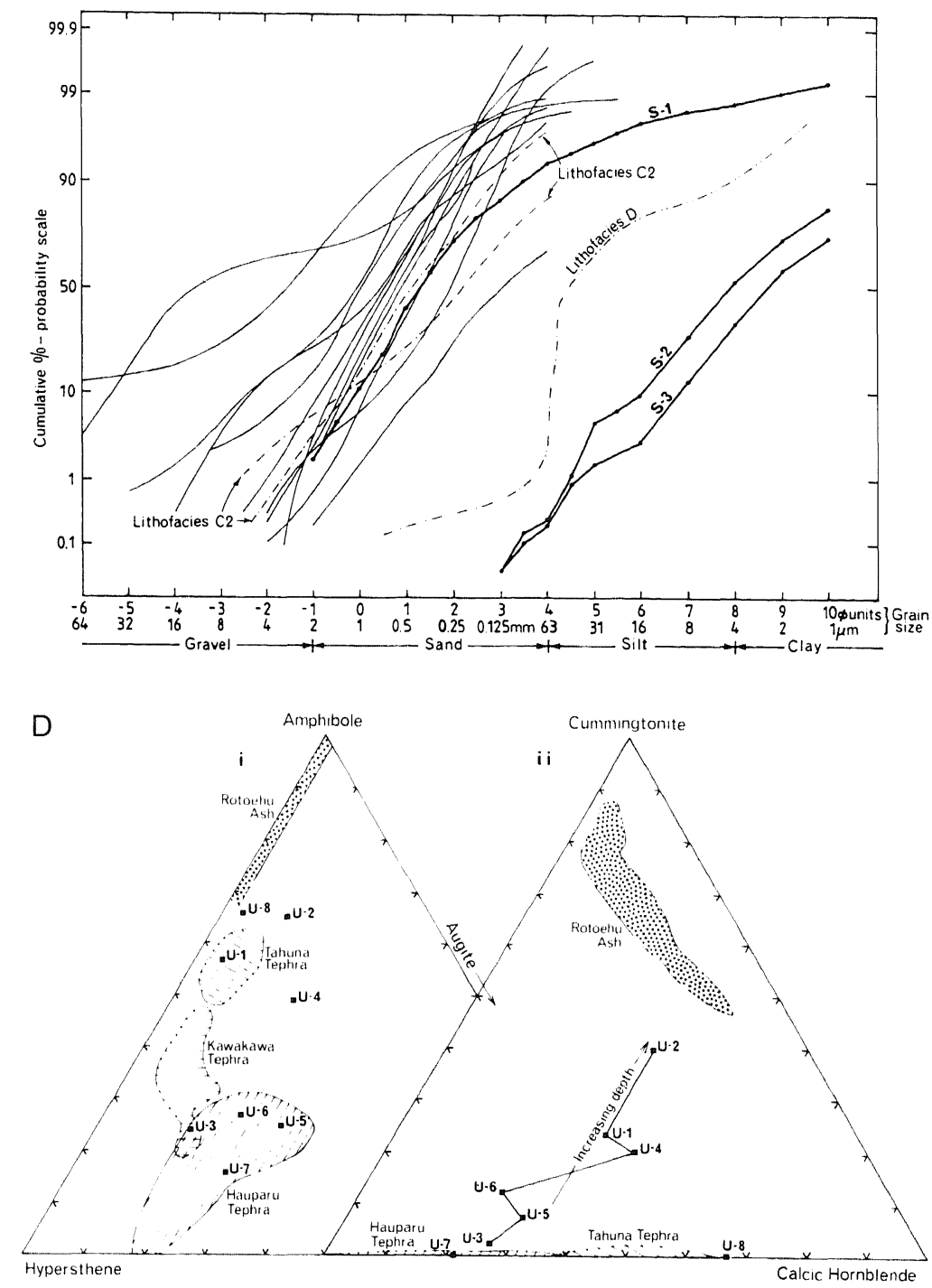

lar \& Birrell 1973). The average age of 12400 years we obtained for Waiohau Ash in Lake Maratoto is significantly older than this. This difference in age may result from an "error" in the Lake Maratoto dates due to contamination by redeposited organic material (cf. Björck \& Håkansson 1982). Alternatively, the previous ages on the Waiohau Ash, all determined on charcoal which is very susceptible to contamination (Hogg 1982), may be underestimates. We prefer the older age (12 400 years), but the age discrepancy nevertheless signifies that the chronology in this zone of the cores is less certain than in the others.

\section{LAKE SEDIMENT CHARACTERISTICS AND SEDIMENTATION RATES}

The characteristics of the four types of lake sediment described are summarised in Table 4. Since the bulk of the sediment probably originates in the catchment, as in other small lakes (e.g., Mackereth 1966), we have made broad inferences about conditions in the catchment using this classification. In addition, we use sedimentation rates to indicate rates of erosion in the catchment.

Sediment type 1 (T1), largely inorganic, suggests that catchment soils had a low organic content with 
Table 3 Mineralogical composition of the sand fractions of subpeat and subgyttja samples at Lake Maratoto*. Compositions of some widespread late Pleistocene tephras (note $\mathrm{d}$ below) and Hinuera Formation sediments are included for comparison with upper unit (U-1 to U-8) and Hinuera (S-1) samples, respectively. Some of the ferromagnesian mineralogical data is plotted in Fig. 7D.

\begin{tabular}{|c|c|c|c|c|c|c|c|c|}
\hline \multirow[b]{3}{*}{ Samples } & \multicolumn{7}{|c|}{ Heavy minerals ${ }^{\mathrm{a}}$} & \multirow{3}{*}{$\begin{array}{c}\text { Light minerals } \\
\text { (relative } \\
\text { abundances) }\end{array}$} \\
\hline & \multicolumn{5}{|c|}{$\begin{array}{l}\text { Ferromagnesian silicate minerals } \\
\text { (summed to } 100 \%)\end{array}$} & \multicolumn{2}{|c|}{$\begin{array}{l}\text { Accessory } \\
\text { minerals } \\
\text { (as \% of } \\
\text { heavy } \\
\text { minerals) }\end{array}$} & \\
\hline & Hyp & Aug & Hbe & $\mathrm{Cgt}$ & Bio & Zir & Mag & \\
\hline Hinuera $^{c}$ & & & & & & & & \\
\hline & 65 & 17 & 17 & 0 & 1 & $\operatorname{tr}$ & 12 & $g \gg f>q$ \\
\hline Hinuera Formation' & 75 & 8 & 14 & 0 & 3 & 0 & 38 & $g \geqslant f \geqslant q \gg 1$ \\
\hline $\begin{array}{l}\text { Upperi unit }(\mathrm{cm}) \dagger \\
\text { U-5 }(5-12) \\
\text { U-3 }(10-15) \\
\text { U-7 } \ddagger(30-33) \\
U-8 \ddagger(40-42) \\
U-6(45-50) \\
U-4(50-55) \\
U-1(60-65) \\
U-2(100-105)\end{array}$ & $\begin{array}{l}45 \\
60 \\
59 \\
31 \\
51 \\
31 \\
40 \\
24\end{array}$ & $\begin{array}{r}30 \\
15 \\
25 \\
3 \\
22 \\
20 \\
4 \\
11\end{array}$ & $\begin{array}{l}20 \\
21 \\
16 \\
65 \\
18 \\
33 \\
34 \\
30\end{array}$ & $\begin{array}{r}5 \\
2 \\
0 \\
1 \\
9 \\
16 \\
22 \\
35\end{array}$ & $\begin{array}{l}0 \\
2 \\
0 \\
0 \\
0 \\
0 \\
0 \\
0\end{array}$ & $\begin{array}{l}2 \\
1 \\
2 \\
3 \\
2 \\
2 \\
1 \\
\operatorname{tr}\end{array}$ & $\begin{array}{r}5 \\
18 \\
6 \\
17 \\
9 \\
7 \\
18 \\
14\end{array}$ & $\begin{array}{l}g \gg f \geqslant q \\
g \gg f \geqslant q \\
g \gg f>q \\
g \gg f>q \\
g \gg f \geqslant q \\
g \gg f \geqslant q \\
g \gg f \geqslant q \\
g \gg f \geqslant q\end{array}$ \\
\hline $\begin{array}{l}\text { Tephra }^{\text {d }} \\
\text { Okareka Ash'.3 } \\
\text { Kawakawa Tephra } \\
\text { Hauparu Tephra } \\
\text { Tahuna Tephra } \\
\text { Rotoehu Ash". } \\
\text { Rot.7 } \\
\text { "Composite"e, } 4\end{array}$ & $\begin{array}{r}16-23 \\
41-62 \\
38-83 \\
32-60 \\
7-16 \\
30-39\end{array}$ & $\begin{array}{c}1-9 \\
2-20 \\
15-38 \\
\operatorname{tr}-12 \\
0-2 \\
11-21\end{array}$ & $\begin{array}{r}20-61 \\
23-53 \\
0-32 \\
26-65 \\
1-44 \\
24-29\end{array}$ & $\begin{array}{c}0-1 \\
0 \\
0-1 \\
0-2 \\
47-91 \\
16-31\end{array}$ & $\begin{array}{c}19-49 \\
0-2 \\
0 \\
0-2 \\
0-2 \\
0-2\end{array}$ & $\begin{array}{c}5 \\
1-2 \\
\text { nd } \\
1-3 \\
1-3 \\
1-2\end{array}$ & $\begin{array}{c}30 \\
33-38 \\
\text { nd } \\
47-54 \\
28-51 \\
32-67\end{array}$ & $\begin{array}{c}g \gg f \geqslant q \\
g \gg f>q \\
n d \\
g \gg f \geqslant q \\
g \gg f>q \\
g \gg f>q\end{array}$ \\
\hline
\end{tabular}

$\mathrm{a}=$ S.G. $>2.9 \mathrm{~g} / \mathrm{cm}^{3}:$ Hyp = hypersthene; Aug = augite; Hbe = calcic hornblende; $\mathrm{Cgt}=$ cummingtonite; Bio = biotite; $\mathrm{Zr}=$ zircon; Mag = predominantly titanomagnetite.

$\mathrm{b}=\mathrm{S} . \mathrm{G} .<2.9 \mathrm{~g} / \mathrm{cm}^{3}: \mathrm{g}=$ glass (and rare pumice); $\mathrm{f}=$ feldspars (mainly plagioclase); $\mathrm{q}=$ quartz; $1=$ lithics.

$\mathrm{c}=$ Hinuera Formation sediments are volcanogenic with diverse mineralogy. Data source: $1=$ Hume et al. (1975).

$\mathrm{d}=$ Widespread rhyolitic tephras of $\mathrm{c} .17000-\mathrm{c} .50000$ years age range that are predicted to be the most likely constituents of the Upper unit. Values show the characteristic range of mineral abundances in each tephra from various localities in the North Island. Data sources and locations are: $2=\mathrm{D}$. J. Lowe, unpublished data (Lake Rotomanuka, Fig. 1); 3 = Howorth et al. (1980) (Poukawa; Gavin Road; Whangamata Road; Okataina area); 4 = Lowe (1981) (Waikato); 5 = Hogg \& McCraw (1983) (Coromandel); 6 = McGlone et al. (1984b) (Bay of Plenty-Gisborne); 7 = Vucetich \& Howorth (1976b) (Taupo). Data in the "Accessory minerals" and "Light minerals" columns are derived wholly from references 2 and 4 above.

$\mathrm{e}=$ "Composite" refers to a composite of pedogenically mixed late Pleistocene and Holocene tephras that occur as c. 50-150 cm thick cover bed deposit on the low hills in the Hamilton City-Lake Maratoto area (Lowe 1981).

${ }^{*}$ Sands $(2-4 \phi)$ were fractionated by sieve and heavy liquid separation methods and analysed by standard petrological microscope (point-count) and X-ray diffraction procedures.

†Depth of sample below base of peat or paleosurface.

$\ddagger U-7$ and $U-8$ occur as discrete, apparently pure tephra layers and probably represent the Hauparu Tephra and Tahuna Tephra, respectively (see text).

$\operatorname{tr}=$ trace amount $(<1 \%)$; nd $=$ not determined. 


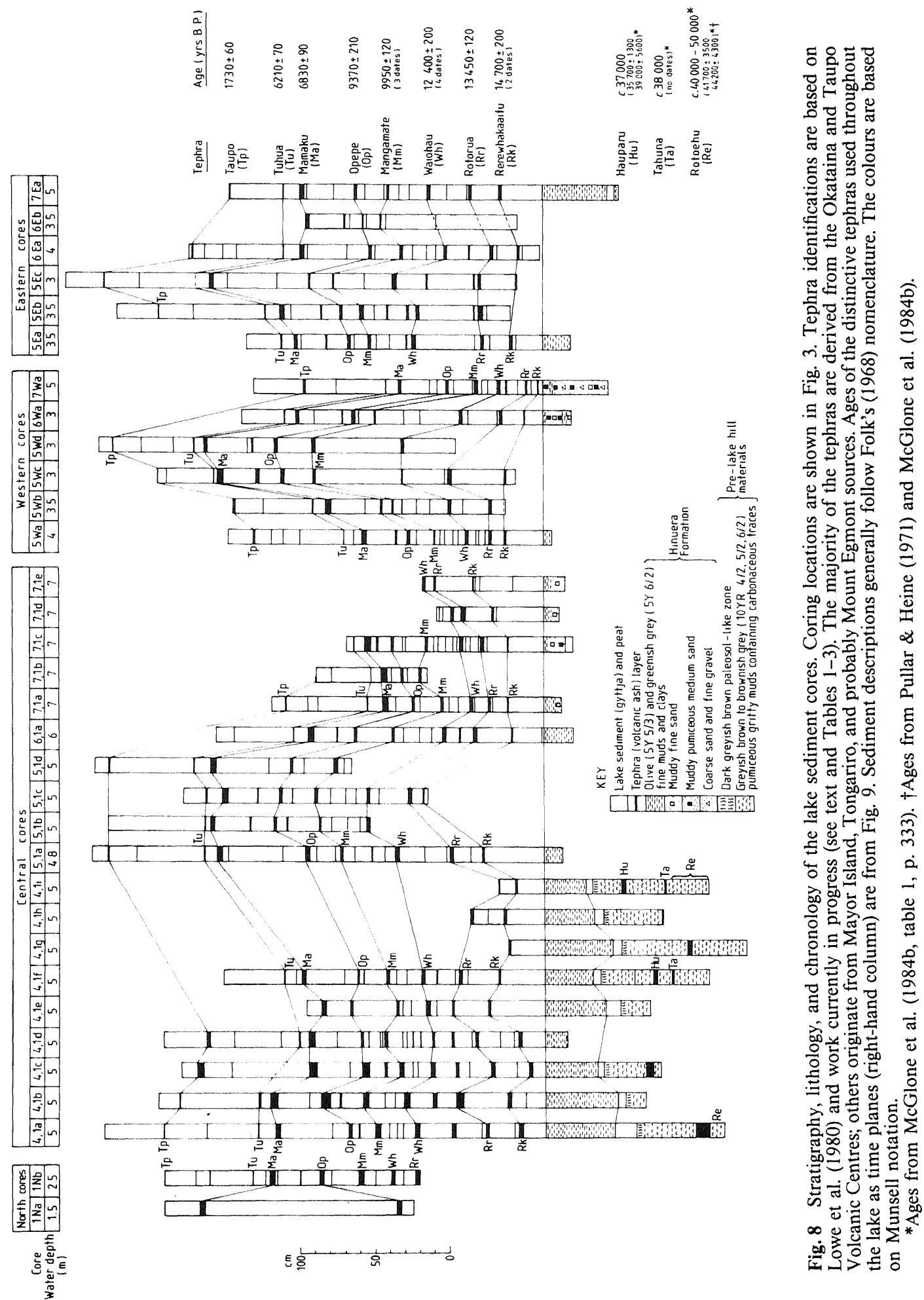




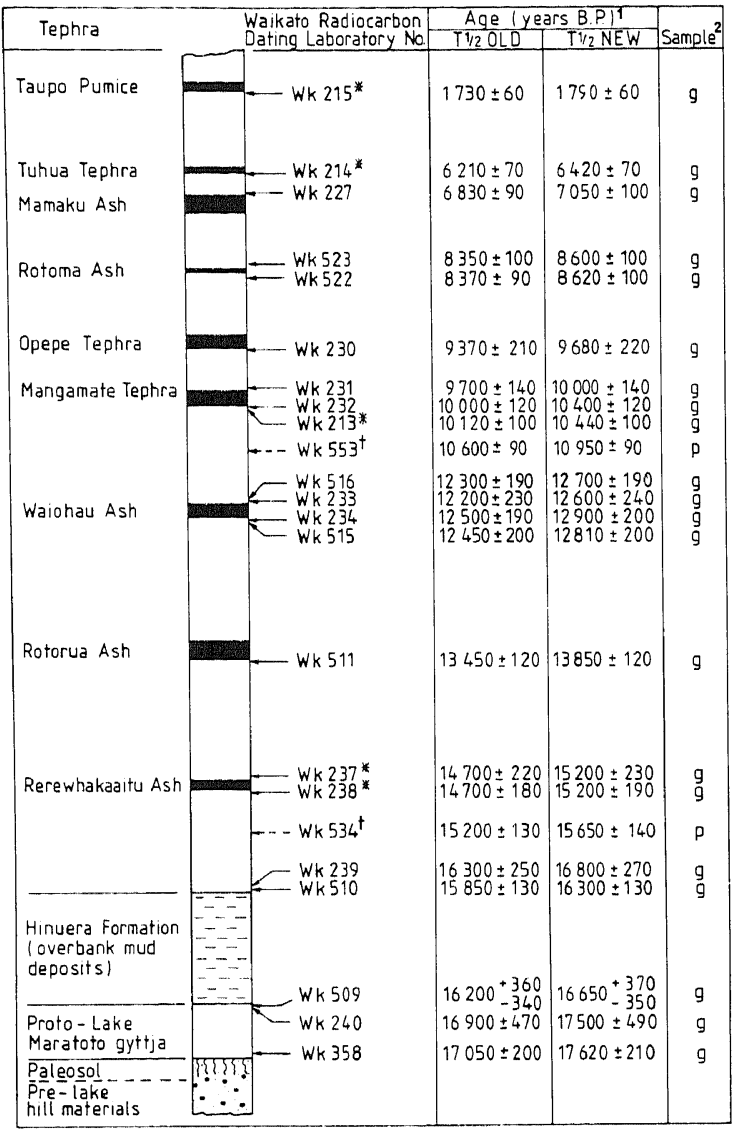

Fig. 9 Summary of radiocarbon dates on gyttja and peat deposits in the Lake Maratoto area. ${ }^{1}$ All ages discussed in the text are old half-life dates. ${ }^{2} \mathrm{~g}=$ gyttja; $\mathrm{p}=$ peat.

*Dates published by Lowe et al. (1980).

†Samples of basal peat in cores GC1 and RJ1 (Fig. 5) stratigraphic positions inferred from ages. Peat sample Wk114 (10250 + 90 years B.P.) was collected from the base of the Rukuhia bog at $8.3 \mathrm{~m}$ depth about 6 $\mathrm{km}$ northwest of Lake Maratoto (near grid ref. S15/076694); sample Wk115 (10 750 + 90 years B.P.; McGlone et al. 1978) was collected at $\overline{9} \mathrm{~m}$ depth about $3 \mathrm{~km}$ north of Lake Maratoto (near S15/119691) (A. G. Hogg pers. comm. 1983). Grid references are based on the national $1000 \mathrm{~m}$ grid of the topographical map series (NZMS 260).

Table 4 General descriptions of four classes of lake sediment in Lake Maratoto.

\begin{tabular}{|c|c|c|c|c|}
\hline Type & Sediment description & $\begin{array}{l}\text { Munsell colour } \\
\text { notation (range) }\end{array}$ & $\begin{array}{l}\text { Organic } \\
\text { matter \%* }\end{array}$ & $\begin{array}{l}\text { Occurrence in present-day } \\
\text { Lake Maratoto } \dagger\end{array}$ \\
\hline $\mathrm{T} 4$ & $\begin{array}{l}\text { Black fibrous soft peaty sediment } \\
\text { containing plant fragments }>2 \mathrm{~mm}\end{array}$ & 10YR $2 / 1$ & 54.2 & $\begin{array}{l}\text { Around lake margins to depths of } \\
1 \mathrm{~m}\end{array}$ \\
\hline T3 & $\begin{array}{l}\text { Black to very dark brown fine soft } \\
\text { dy-gyttja. Particles }<1 \mathrm{~mm}\end{array}$ & $\begin{array}{l}\text { 1OYR } 2 / 1 \\
\text { 1OYR } 2 / 2\end{array}$ & 42.7 & Water depths $>1 \mathrm{~m}$ \\
\hline $\mathrm{T} 2$ & $\begin{array}{l}\text { Very dark grey to very dark } \\
\text { greyish-brown firm fine gyttja. } \\
\text { Particles }<1 \mathrm{~mm}\end{array}$ & $\begin{array}{l}\text { 10YR } 3 / 1 \\
10 Y R 3 / 2 \\
2.5 Y 3 / 2\end{array}$ & 18.9 & Not found in surficial sediments \\
\hline $\mathrm{T} 1$ & $\begin{array}{l}\text { Olive to very dark grey, firm } \\
\text { slightly sticky fine gyttja. } \\
\text { Particles }<1 \mathrm{~mm}\end{array}$ & $\begin{array}{l}5 Y 3 / 1 \\
5 Y 3 / 2 \\
5 Y 4 / 3\end{array}$ & 9.1 & Not found in surficial sediments \\
\hline
\end{tabular}

*Loss on ignition determined on at least two samples of dried sediment by combusting at $550^{\circ} \mathrm{C}$ for $30 \mathrm{~min}$. †From Boubée (1983). 


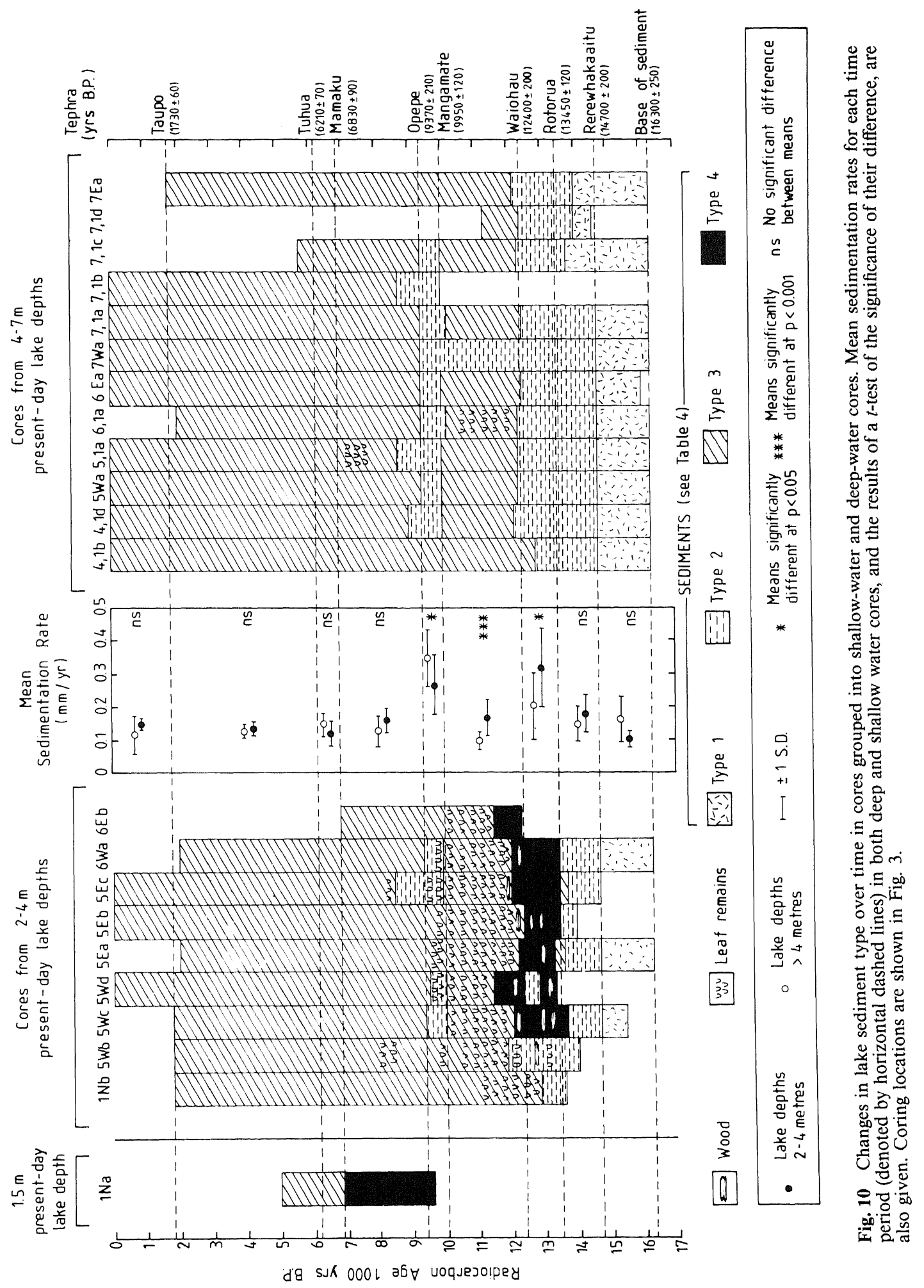




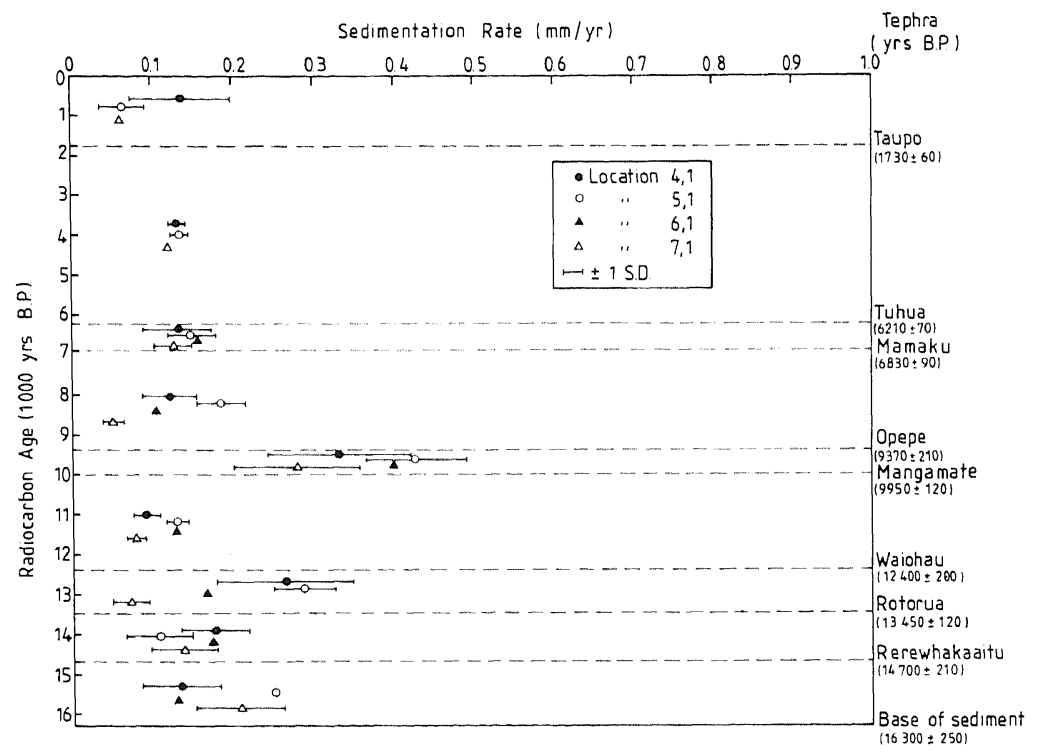

Fig. 11 Sedimentation rates in cores taken from central locations (along transect $1-1^{\prime}$ in Fig. 3 ) and averaged for each designated time period (denoted by horizontal dashed lines).

little vegetational cover. The greenish tinge of this sediment is due largely to secondary chlorophyll degradation products, possibly produced within the lake itself. The lack of brown staining implies that the lake water was clear. The browner $\mathrm{T} 2$, with higher organic content, suggests more vegetation in the catchment and soils with greater organic content. Marginal vegetation may have contributed also to its darker colour. The very dark peaty T3 consists of decomposing remains of aquatic plants and animals, faecal pellets of aquatic animals, and fine plant remains from surrounding terrestrial vegetation (Boubée 1983), and is stained with humic material extractable with $10 \% \mathrm{KOH}$. Such sediment, often described as dy-gyttja (e.g., Hansen in Berg \& Petersen 1956), shows dystrophic conditions in the lake and considerable peat development around it. Leafy fragments occur in T3 sediment within and around beds of the sedge Eleocharis sphacelata. T4 sediment is fibrous and woody and is similar to peat from the Rukuhia bog. It is found around the margins of the present-day lake (Table 4).

Changes in sediment type and sedimentation rates were examined in two groups of the lake sediment cores - those taken from modern lake depths shallower than $4 \mathrm{~m}$ (shallow-water cores) and those taken from depths deeper than $4 \mathrm{~m}$ (deep-water cores) (Fig. 10).

The temporal sequence is similar in most of the deep-water cores (Fig. 10, right panel). Sediment T1 occurs from c. 16300 to 14700 years ago, T2 from 14700 to c. 12400 years ago, and T3 thereafter, except for a brief period of T2 deposition from
10000 to c. 9000 years ago. No T4 or wood was found in the deep-water cores, and leaf remains are rare. Most of the shallow-water cores (Fig. 10, left panel) differ from the deep-water cores in having a band of woody T4 from c. 13500 to c. 12000 years ago, leafy T3 from c. 12000 to 10000 years ago, and a less-obvious zone of T2 from c. 10000 to 9000 years ago.

For most of the lake's history (c. $16300-13500$ years ago, c. $12400-10000$ years ago, and c. 9000 years ago to present) (Fig. 10), mean sedimentation rates were slow (0.10-0.20 mm/year). For two brief periods, from c. 13500 to 12400 years ago, and from c. 10000 to 9000 years ago, the sedimentation rate was faster $(0.20-0.35 \mathrm{~mm} /$ year $)$.

There was no significant difference in sedimentation rate between shallow and deep water cores early (c. $16300-13500$ years ago) and late (from c. 9000 years ago to present) in the lake's history. However, from c. 13500 to 10000 years ago, sedimentation rates in shallow water were significantly faster than in deep water. During this period, sediment types T4 and leafy T3 were deposited in shallow water. In contrast, from c. 10000 to 9000 years ago, sedimentation rate was significantly faster in deep water, coinciding with T2 deposition. This was the only period of sediment focussing (i.e., greater accumulation of sediment in the deepest part of a lake basin; Davis \& Ford 1982) in the lake's history.

In central locations (along transect $1-1^{\prime}$; Fig. 3), between c. 16300 and 12400 years ago, sedimentation rates declined in the south of the lake (location 7,1 ) but increased in the northern $(4,1)$ and middle $(5,1)$ locations (Fig. 11). Thereafter, 
Table 5 Total lake sediment thickness in central locations.*

\begin{tabular}{lcc}
\hline Location & $\begin{array}{c}\text { No. of cores used } \\
\text { in calculation }\end{array}$ & $\begin{array}{c}\text { Sediment } \\
\text { thickness }(\mathrm{cm})\end{array}$ \\
\hline 4,1 & 4 & 259 \\
5,1 & 1 & 310 \\
6,1 & 1 & 251 \\
7,1 & 2 & 201 \\
\hline
\end{tabular}

*Data also plotted in transect $1-1^{\prime}$, Fig. 4.

from c. 13500 to 7000 years ago, sedimentation rate was consistently slowest in the south and fastest in the middle (narrow) area of the lake. The faster sedimentation rates in location 5,1 from c. 13500 to 7000 years ago account for the greater total sediment thickness there (Table 5). From c. 7000 to 2000 years ago, sedimentation rate was similar in all central locations. Sedimentation rates were faster in the northern basin $(4,1)$ from c. 2000 years ago to the present.

In the central locations (transect $1-1^{\prime}$ ), sedimentation rates were inversely proportional to the distance from the shoreline (e.g., station 7,1 is 150 $\mathrm{m}$, and station 5,1 is $50 \mathrm{~m}$, from the shore), suggesting that input of littoral and terrestrial material is the major factor determining the sedimentation rates in Lake Maratoto.

\section{DEVELOPMENTAL HISTORY}

\section{Origin of the lake basin}

Beneath the lake is a shallow, elongated, northeastsouthwest-orientated depression. This is an embayment in the Pleistocene hills which is dammed to the southwest by Hinuera sands and gravels and floored by Hinuera muds and clays (Fig. 12). The southwest margin of the paleosurface depression, made up of these Hinuera sands and gravels, is lower lying than the low ridges and Pleistocene hills around its other sides. The lake is thus held at its present level mainly by the $8 \mathrm{~m}$ depth of peat overlying the sands and gravels to the southwest.

The Hinuera sediments blocking the embayment were laid down in two main episodes (Fig. 13), the first of which occurred c. 17000 years ago forming a proto-Lake Maratoto in which the thin layer of gyttja lying beneath the Hinuera muds was deposited. The proto-Lake Maratoto gyttja lies directly on the Pleistocene hill derived materials in the valley floor with no intervening layer of Hinuera muds, at least in the northern part of the lake basin. This suggests either that there was no extensive flooding by mud-laden river water, possibly because the major course of the Waikato River moved some distance away from the mouth of the valley after deposition of the dam materials, or that the basin was too shallow to hold enough water to produce an appreciable thickness of mud. Whichever, this proto-Lake Maratoto sediment was laid down in what may have been a swampy hollow with only shallow water. The duration of the proto-lake was between 150 and 800 years (Fig. 9).

The second episode of Hinuera deposition, that produced the initial modern lake basin, was more extensive and rapid. There must have been a considerable depth of floodwater ponded in the valley to act as a buffer to the river current to produce the sorted nature of Hinuera deposits in the embayment (Fig. 13). The alternating sand and mud layers found in the base of the cores from the southwest of the lake and in GC1 (Fig. 5, 8) suggest that the ponded mud-laden water was renewed in a series of floods. This is consistent with what is inferred about Hinuera Formation deposition by Hume et al. (1975) who deduced that the river formed an extensive braided channel system with high flow-rates and subject to periodic flooding and channel movements. Hume et al. (1975) identified several lithofacies related to flow regimes, and their lithofacies $\mathrm{C} 2$, formed by plane bed movements on the surface of longitudinal bars at higher discharges, is very similar to the gravelly sands in core $7 \mathrm{Wa}$ (Fig. 7C, 8). The presence of such deposits at this site shows that, at least during periods of high flow, the main channel system of the river flowed near the mouth of the valley. The river may have flowed in a north-south direction broadly along the course shown in Fig. 1 from the site of the presentday Hamilton Airport, past the lake, and then west into the Waipa River near Te Rore. Lakes Cameron, Ruatuna, Ngaroto, and Mangakaware, which lie adjacent to this paleochannel, are thus likely to have been formed at the same time, and in the same way, as Lake Maratoto.

\section{Development of the lake basin and catchment}

Initially, the lake was probably no larger than it is today because fine gyttja does not occur in the RJ 1 core at the southwestern edge of the lake nor in $\mathrm{GC} 3$ only $10 \mathrm{~m}$ from the northern lake shore. At c. 16300 years ago, the shoreline probably lay between the 7 and $8 \mathrm{~m}$ palzobasin contours (Fig. 12). The RJ 1 core site lies on the $7 \mathrm{~m}$ contour and was clearly either above water or close enough to the shoreline for wave action to remove any gyttja to deeper water. The $8 \mathrm{~m}$ contour, however, seems to have been under water from the start of the lake's development, and cores from sites $5 \mathrm{~W}, 6 \mathrm{~W}$, and $7 \mathrm{~W}$, that are on or close to this contour line, have 


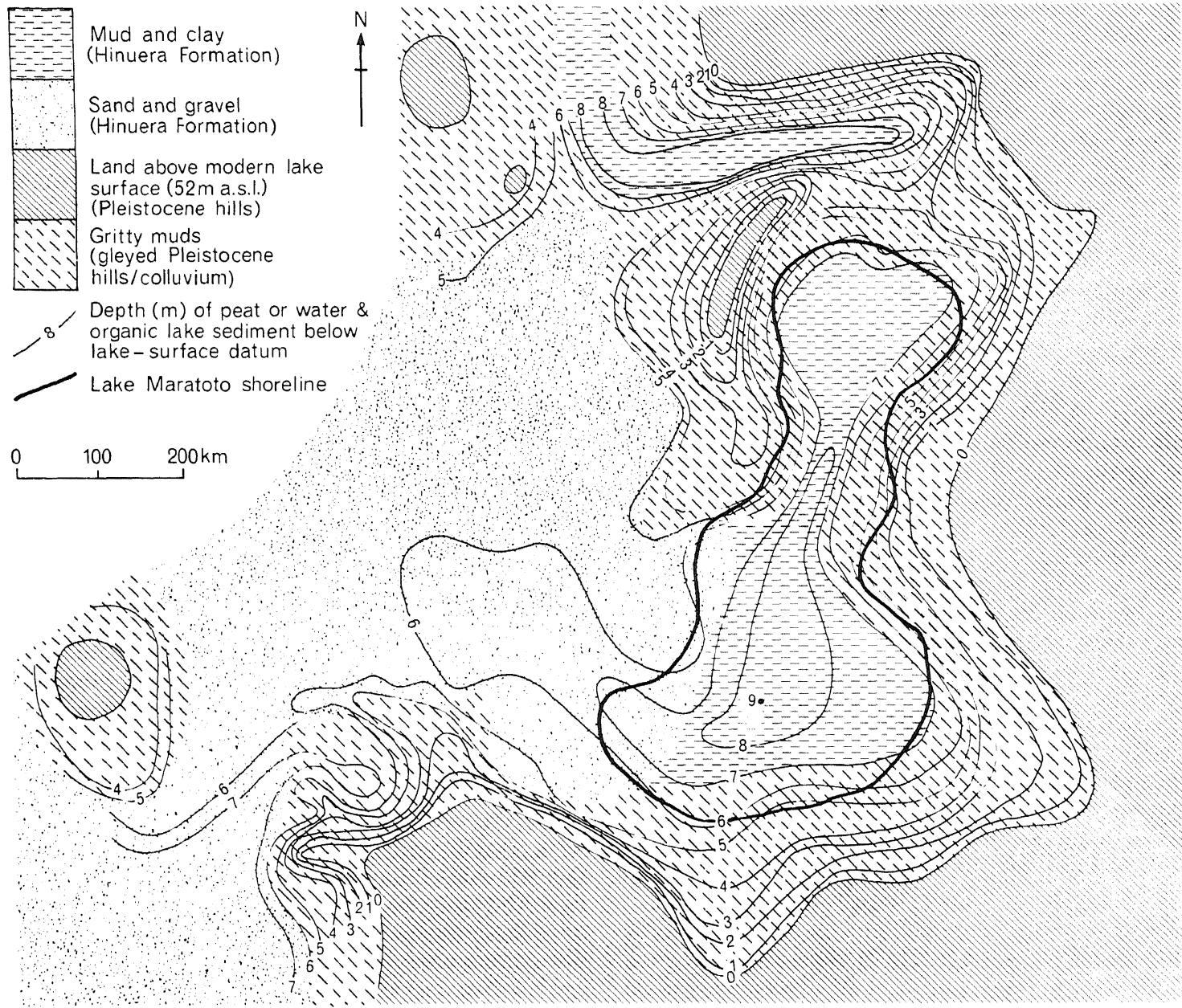

Fig. 12 Subsurface materials and topography of the Lake Maratoto area, derived from the transect profiles in Fig. 4. The $0 \mathrm{~m}$ contour is the lake-surface datum $(52 \mathrm{~m}$ altitude). The map shows the northeast-southwest-orientated depression in which the modern lake (heavy line) lies. A separate, narrow, east-west-orientated paleovalley occurs to the north of Lake Maratoto. See also Fig. 13.

a considerable thickness of gyttja between the Hinuera overbank muds and the Rerewhakaaitu tephra. The lake would thus have been about $2 \mathrm{~m}$ deep in its early stages.

The subsequent development of the lake has been largely governed by the massive growth of peat around its margins and in the adjacent Rukuhia bog, as well as by the accumulation of gyttja. Peat growth has modified the basin configuration (area and depth) and water chemistry.

There was little or no peat development during the first 1000 years or so of the lake's history. The type of sediment deposited shows that lake water was clear and that, in the catchment, soils were low in organic matter, with probably little vegetational cover. From pollen analyses of peat lenses, McGlone et al. (1978) and McGlone et al. (1984a) concluded that there was sparse vegetation in the Hamilton region at this time.

Peat began to accumulate around the lake about 15000 years ago, as shown by the date (Wk534) of $15200 \pm 130$ years ago at the base of RJ1. The appearance of darker coloured T2 in the lake may have resulted from such peat development although other factors, such as increasing vegetational cover in the catchment, may have been important. Elsewhere in the central North Island, 14700 years B.P. marked the beginning of major podocarp forest expansion (e.g., McGlone \& Topping 1977; Flem- 

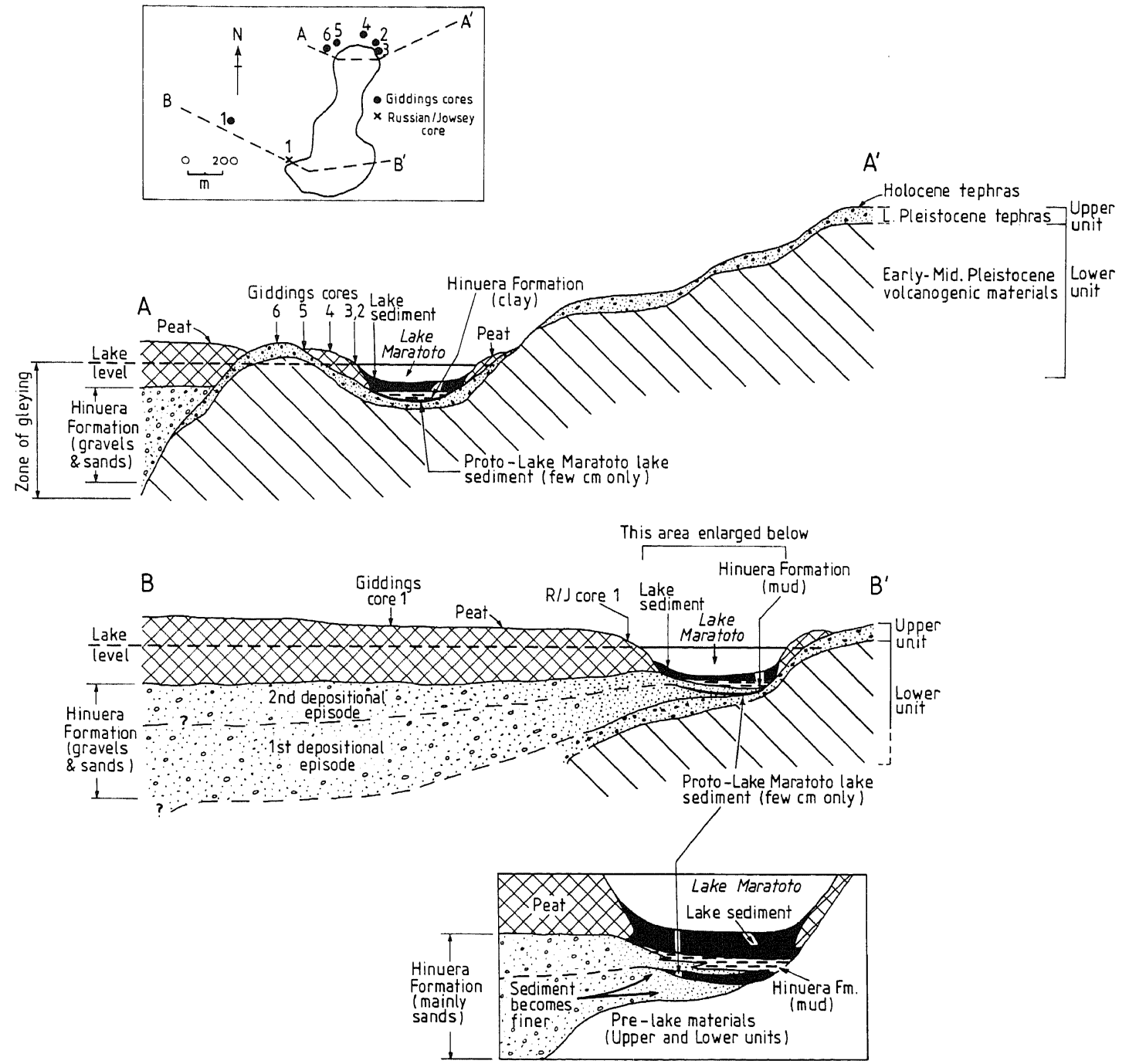

Fig. 13 Schematic cross sections summarising the stratigraphic units and their relationship to one another in the Lake Maratoto area, showing especially the differences between the northern and southern parts of the lake basin. There is a time gap of a few hundred years between the Hinuera depositional episodes shown in B- $\mathbf{B}^{\prime}$, but note that both occurred within the Hinuera-2 sedimentation phase of McGlone et al. (1978).

ing 1979) and an increase in rates of soil formation (e.g., Vucetich \& Pullar 1969; Birrell \& Pullar 1973). This early peat development must have been fairly localised because the change to T3, marking the onset of dystrophy, did not occur until c. 12400 years ago, and peat did not appear at the GC1 site, only $400 \mathrm{~m}$ from the lake, until (Wk553) $10600 \pm$ 90 years ago. Thus it seems peat first developed near the lake and then spread outwards.

Dates from peat at the base of the main body of the Rukuhia bog $(10750 \pm 90$ years B.P. (Wk1 15)
McGlone et al. 1978; $10250 \pm 90$ years B.P. (Wk114) unpublished) (Fig. 9) are similar to that for $\mathrm{GCl}$, showing that most bog development occurred after c. 11000 years ago. Peat bogs began developing at other sites in the Waikato region (e.g., Hauraki and Moanatuatua bogs-Schofield 1965; McGlone et al. 1978; Hogg \& McCraw 1983) and elsewhere in the North Island (McGlone \& Topping 1977; Lowe \& Hogg in press) at about this time also, which suggests that climatic change resulting in an increase in net precipitation, and 

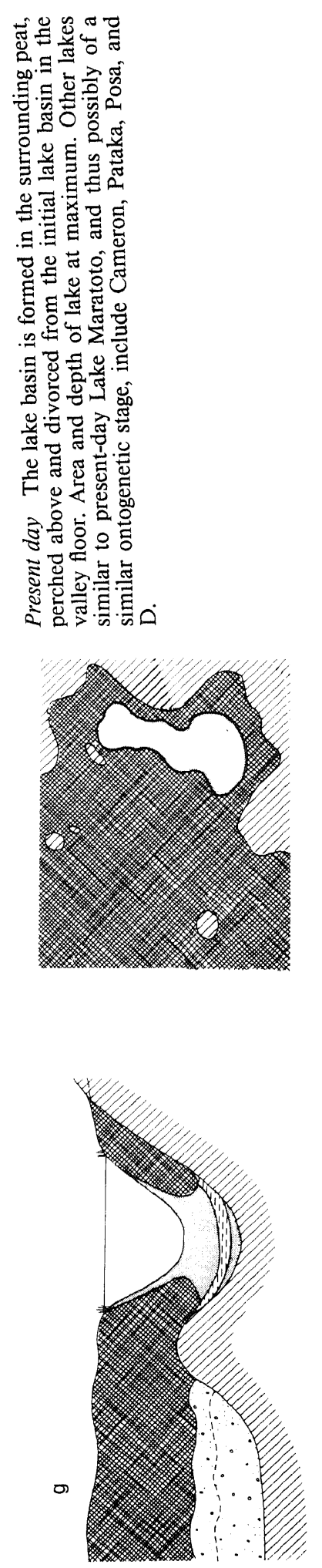
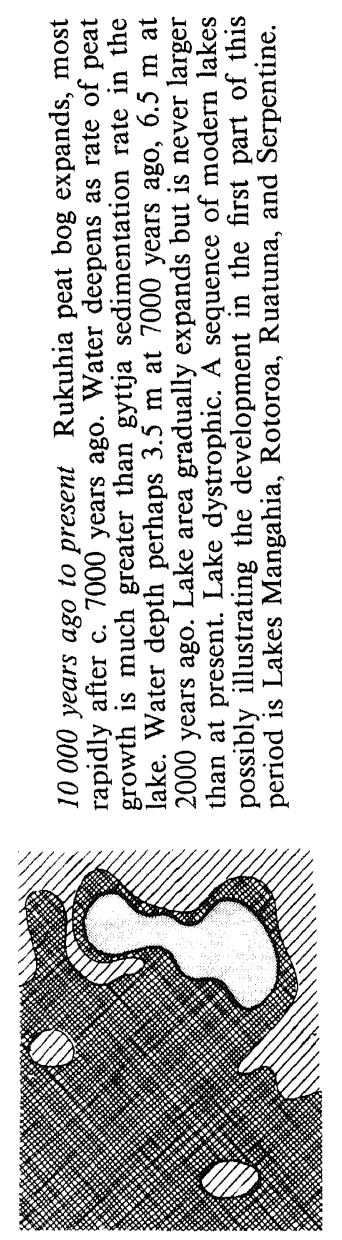

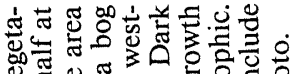

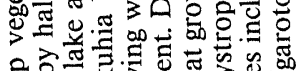

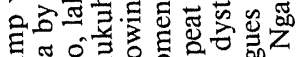

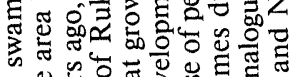

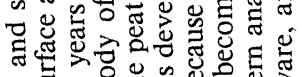

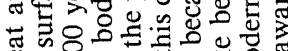

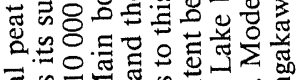

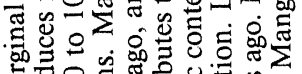

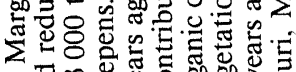

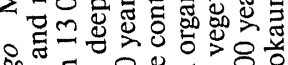
8 을

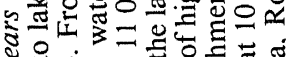

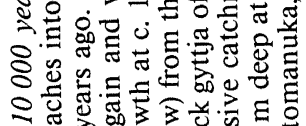

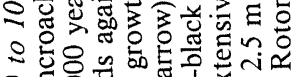
8

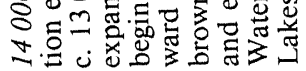

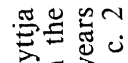
仓.

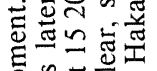

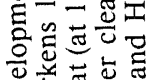

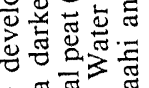

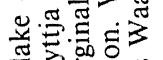

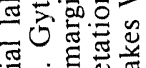
恶它焉焉

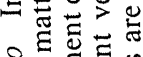
\&. 응

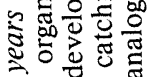
$8 . \Xi \div \frac{2}{8}$

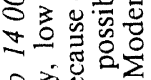
8 항ㅎํ ก.己.
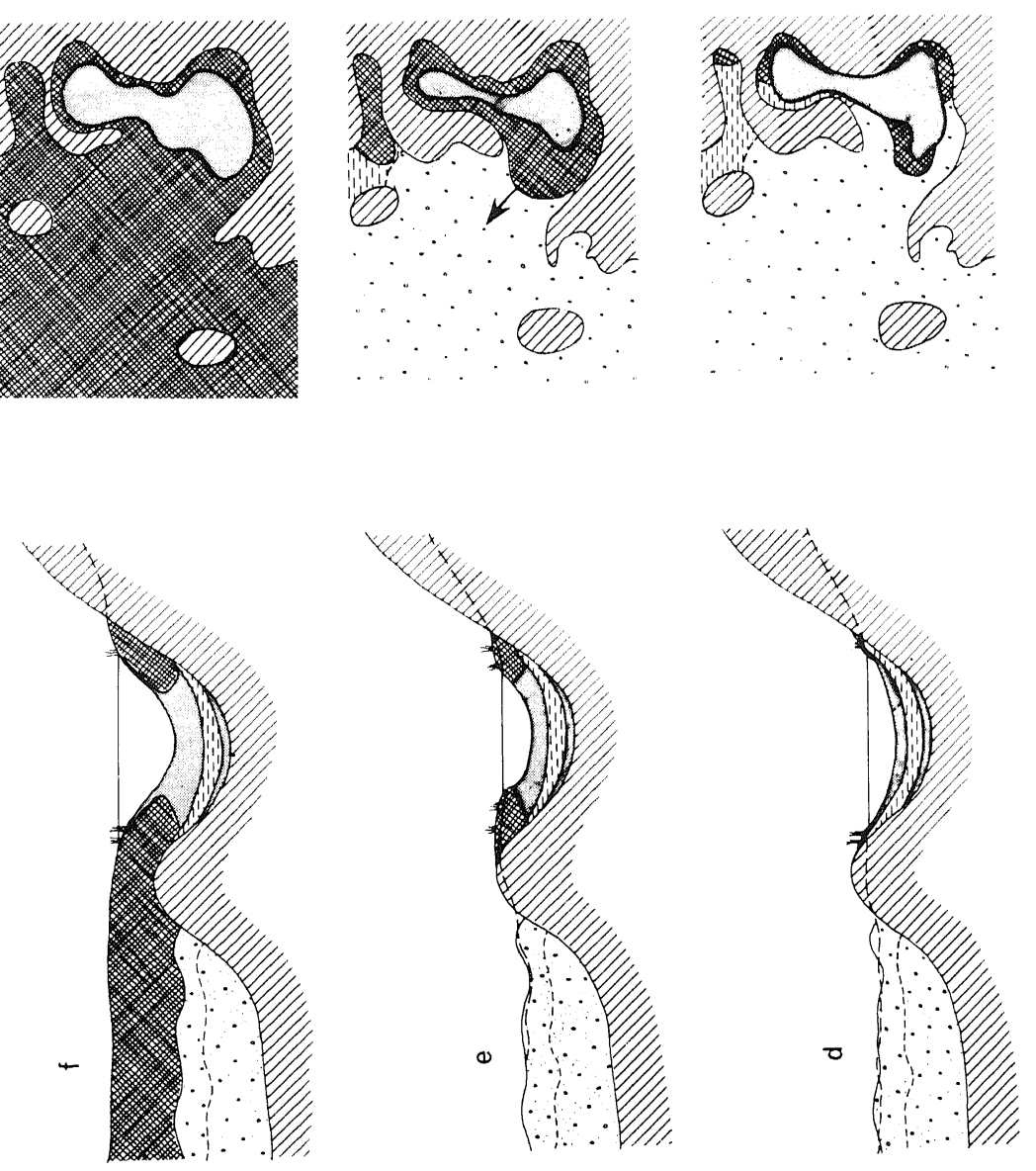
Green \& Lowe-Stratigraphy \& development of L. Maratoto
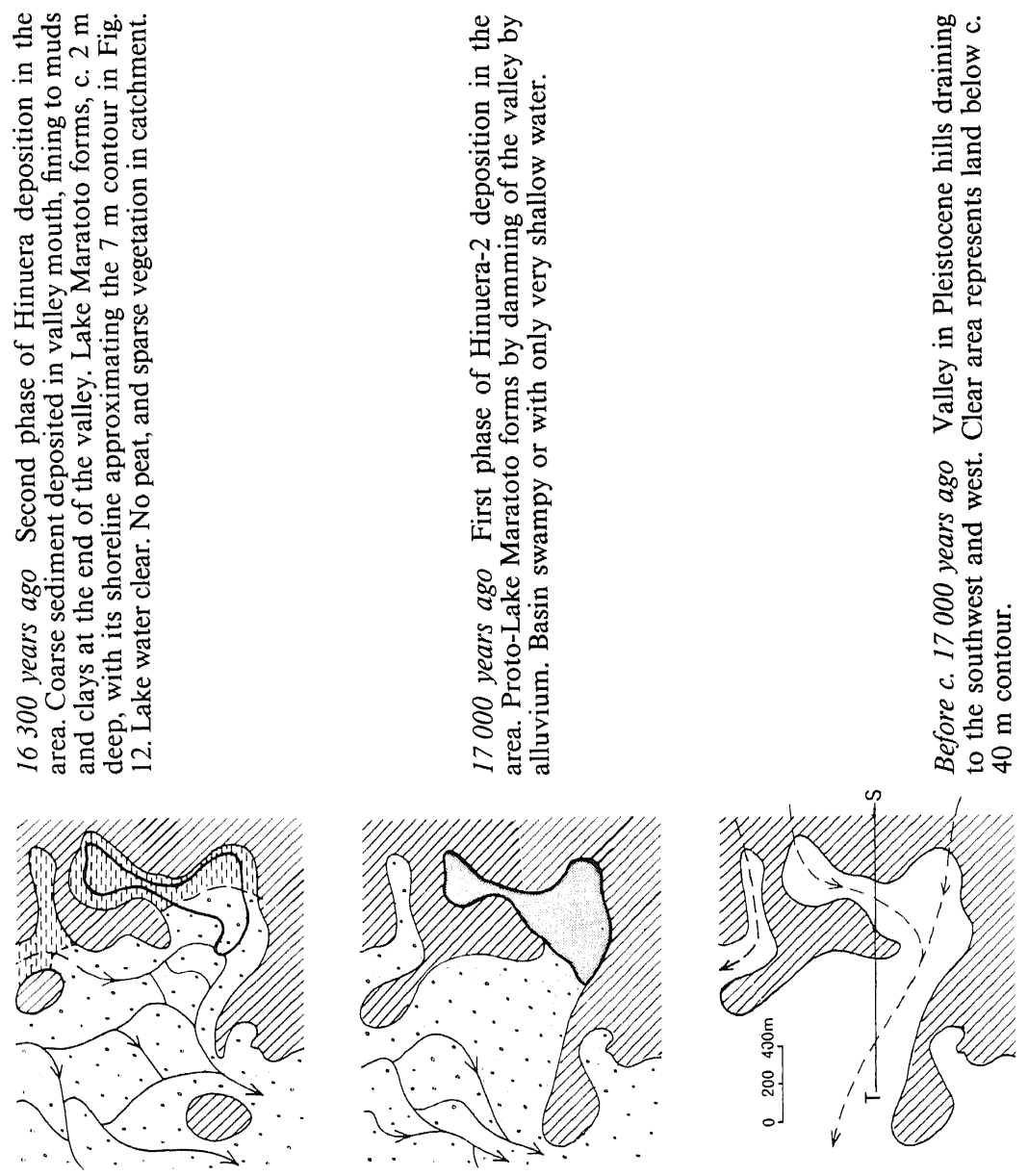

일

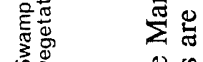

का

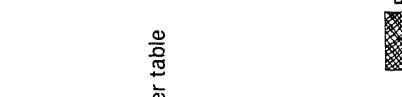

1
$\square$
0

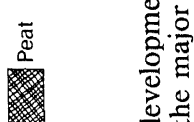
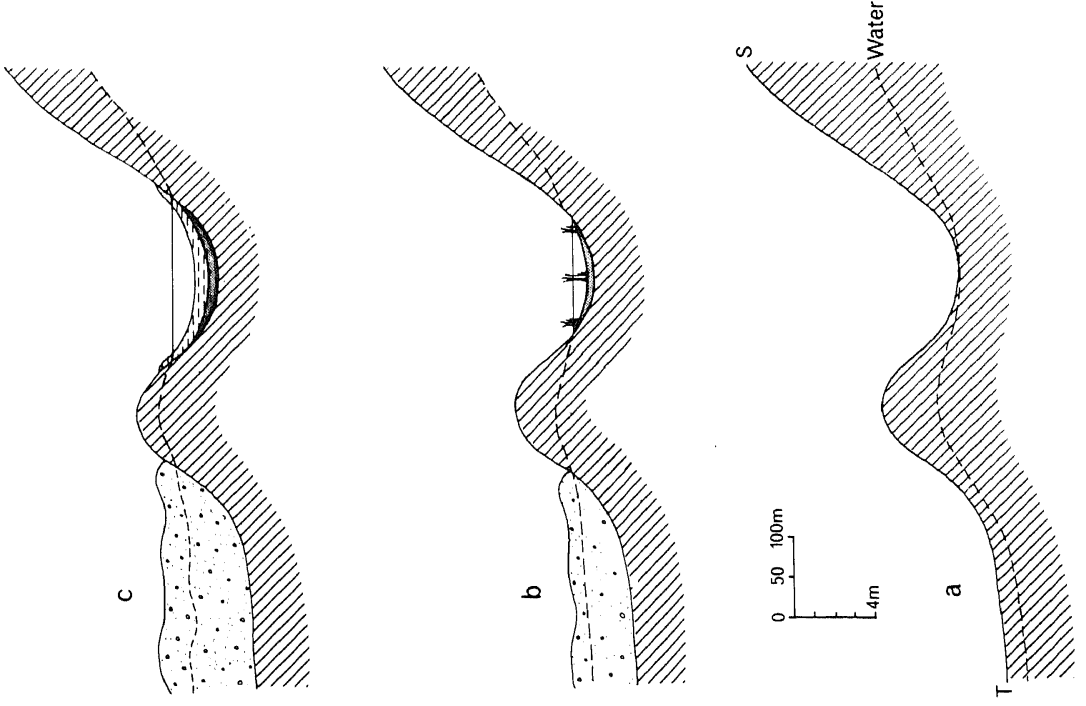

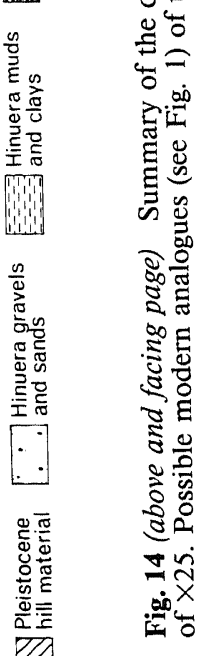


not local-changes in drainage patterns, initiated the development of the bog.

The dystrophic conditions induced in the lake by the development of the Rukuhia bog have continued to the present, except for the brief period of T2 deposition from c. 10000 to 9000 years ago. This was probably a time of increased input of material derived from erosion of surrounding soils because $\mathrm{T} 2$ has a higher inorganic content than $\mathrm{T} 3$. Possible explanations include sustained high rainfall, or disruption of catchment vegetation by events such as fire, drought, or increased storminess. Sediment focussing also occurred during this period, with greater transport of littoral material to the centre of the lake by (presumably) increased wave erosion at the shoreline. Such focussing is consistent with wetter or windier weather at this time.

The vertical distance between the bases of cores $\mathrm{RJ} 1$ and $\mathrm{GCl}$ is $1.1 \mathrm{~m}$ and their respective ages are 15200 and 10600 years, so $1.1 \mathrm{~m}$ of peat accumulated in this time interval (4600 years), a net peat accumulation rate of $0.03 \mathrm{~cm} /$ year. This peat growth would not have greatly affected the lake depth because in this period about $65 \mathrm{~cm}$ of lake sediment was deposited. The net change of lake depth was thus $45 \mathrm{~cm}$ and the rate of increase in water depth was $0.01 \mathrm{~cm} /$ year. The lake would thus have been about $2.5 \mathrm{~m}$ deep at 10600 years ago. The main body of the Rukuhia bog developed after c. 10600 years ago, and with a much greater net peat accumulation rate (e.g., at $\mathrm{GCl}, 8 \mathrm{~m}$ of peat has accumulated since then, giving a net peat accumulation rate of $0.08 \mathrm{~cm} /$ year, treble the rate between 15200 and 10600 years ago). Similar rates of $0.10,0.06$, and $0.08 \mathrm{~cm} /$ year (average 0.08 $\mathrm{cm} /$ year) were estimated from peat depths between Mamaku tephra and Taupo tephra in cores RJ1, GC2, and GC3, respectively (Fig. 5).

This rapid peat growth around Lake Maratoto resulted in rapid deepening of the water. From 10600 years ago to the present, the rate of peat growth was much greater than the rate of accumulation of lake sediment, and lake depth increased by $4.6 \mathrm{~m}$, a change of $0.04 \mathrm{~cm} /$ year, four times the rate before 10600 years ago. Assuming that the positions of the Mamaku and Taupo tephras in the peat cores mark the approximate level of the lake surface when they were deposited, and that the peat has not been compressed, we estimate that lake depth was $3.5 \mathrm{~m} \mathrm{c}$. 7000 years ago and $6.4 \mathrm{~m} \mathrm{c}$. 1800 years ago. Thus, between 10600 and 7000 years ago, the rate of change of lake water depth was $0.03 \mathrm{~cm} /$ year; between 7000 and 1800 years ago, $0.06 \mathrm{~cm} /$ year; and from 1800 years ago to the present, $0.04 \mathrm{~cm} /$ year. Thus, lake depth has increased markedly in the last 11000 years, but particularly since 7000 years ago.
Variations in the spatial pattern of the deposition of lake sediment have resulted in minor modifications to the bathymetry. Early in the lake's history, lake depth gradually increased from north to south, but because sedimentation rates were fastest in the region of core location 5,1 (because of nearness to the shoreline), there is now a shallower zone in the narrow waist of the lake (Fig. 2).

Although the area of the lake in its early stages was probably similar to that of today, the band of woody T4 sediment in the shallow-water cores between c. 13500 and 12400 years ago (Fig. 10) shows that during this period the lake margin moved inward to lie near the position of these coring sites, between the $3 \mathrm{~m}$ and $4 \mathrm{~m}$ water depth contours. The change to leafy T3 sediment between c. 12400 to 10000 years ago at these sites shows that the shoreline moved outward again, but was still close to the $3 \mathrm{~m}$ and $4 \mathrm{~m}$ depth contours. The faster rates of sedimentation in shallow-water cores from 13500 to 10000 years ago reflect this proximity of the shoreline to the coring sites and also suggest little movement of littoral material into deeper water. The disappearance of leafy T3 sediment from the shallow-water cores after about 10000 years ago shows that lake area continued to expand. The shoreline reached the present $1.5 \mathrm{~m}$ water depth contour at about 7000 years ago, as shown by the abrupt transition from T4 to T3 sediment at this time in core $1 \mathrm{Na}$ (Fig. 10). Thereafter, expansion continued to the present day. This shoreline expansion in the last 10000 years occurred together with the increase in water depth.

Throughout its history, the lake has never been larger than it is now, while at its minimum at c. 13000 years ago, the area of open water was only about one-half that of today (7.6 ha using the 3.5 $m$ depth contour).

Most lakes occupying basins in which peat development is occurring are gradually reduced in area and depth by centripetal peat growth that eventually develops into zones of "quaking bog", made of floating mats of encroaching peat vegetation and often supporting large trees (Moss 1980). The final result of this process is extinction of the lake. The complete process from lake origin to extinction can take less than about 12000 years in the Northern Hemisphere (e.g., Pigott \& Pigott 1963; Walker 1970). The only lake we know of which has a similar developmental history to Lake Maratoto is Myrtle Lake, in the Agassiz peatland area of Minnesota (Heinselman 1970). This lake originated as an embayment blocked by alluvium c. 10000 years ago and, like Lake Maratoto, has maintained its area and increased its depth despite massive peat growth in the catchment during the last 3000-5000 years. Heinselman (1970) suggested 
that because of Myrtle Lake's location adjacent to higher areas of mineral soil, it would have continually received minerotrophic water that has enhanced microbial breakdown of the encroaching peat. This explanation may apply to Lake Maratoto as well because there is only a narrow zone of peat between the lake water and the Pleistocene hills to the east (Fig. 2, 4). Also, these hills rise considerably above the lake's surface which would encourage greater flow rates of minerogenic ground and surface water into the lake during heavy rainfall.

Other mechanisms may also be involved in the expansion of Lake Maratoto's area. Wells \& Boyce (1953) and Frey (1954) suggested that erosion of peat margins by wave action may have been a factor in the development of the Carolina Bays (North Carolina). This almost certainly occurs in Lake Maratoto. In the present-day lake, a vertical $50 \mathrm{~cm}$ high bank is maintained around the lake margins, particularly at the north and south ends, by wave action produced by the prevailing southwest and northerly winds. Wind-induced currents stir and aerate the lake waters for most of the year. The lake develops thermal stratification and deoxygenated bottom waters for only a few months in the summer (Boubée 1983), hence the lake waters are usually saturated or supersaturated with oxygen which will enhance organic breakdown.

Our interpretation of the development of the lake basin in summarised in Fig. 14, along with possible modern analogues of the major developmental stages.

\section{CLIMATIC INFERENCES}

Between c. 17000 and 15000 years ago, there seemed to be no peat development near the lake. The first appearance of peat at c. 15000 years ago may indicate that effective rainfall increased at this time. Subsequently, net peat accumulation rate, regional water tables, and lake level rose continually until c. 2000 years ago. The major part of the Rukuhia peat bog developed after c. 11000 years ago, but the fastest growth rates, and thus highest net precipitation rates, were apparently not until after c. 7000 years ago. Regional postglacial climatic warming, reaching a maximum at c. 9000 years ago (Hendy \& Wilson 1968), may also have contributed to the peat growth.

In summary, there was a sudden increase in net precipitation at c. 15000 years ago followed by further increases at c. 11000 years ago continuing to c. 7000 years ago at least, but with a decline at or before c. 2000 years ago. The period from c. $10000-$ 9000 years ago may have been distinctly wetter or windier, or both. These inferences are consistent

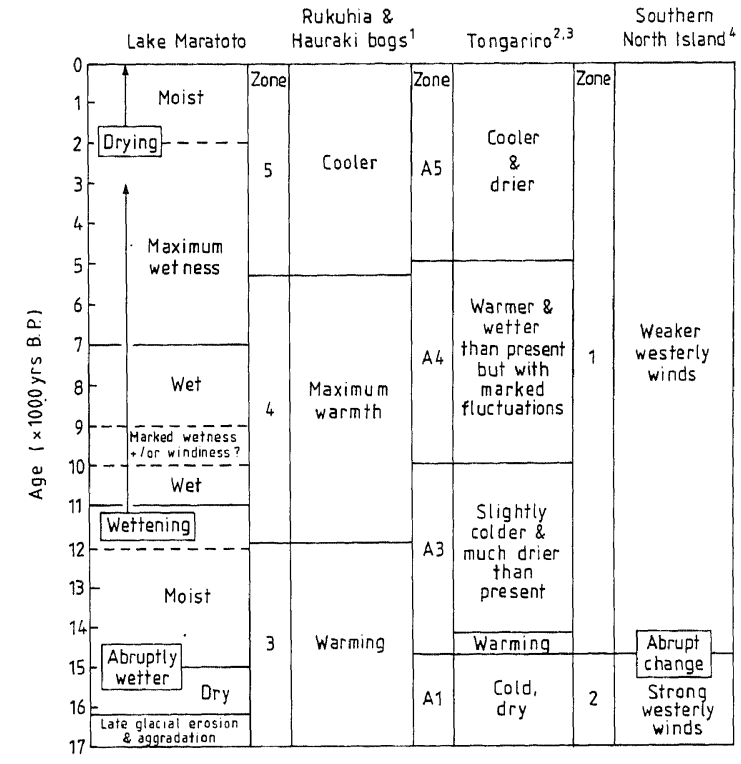

Fig. 15 Inferred changes in climate in the Lake Maratoto area compared with interpretations from some other North Island sites. References are: 1, Harris (1963); 2 McGlone \& Topping (1977); 3, McGlone \& Topping (1983); 4, Stewart \& Neall (1984).

with late-glacial and postglacial climatic interpretations from other studies in the North Island of New Zealand (Fig. 15) (McGlone 1983; McGlone et al. 1984a) and elsewhere in the Southern Hemisphere (e.g., Burrows 1979; Street \& Grove 1979; Heusser \& Streeter 1980; Colhoun et al. 1982).

\section{ACKNOWLEDGMENTS}

We acknowledge valuable help in the field by Drs $\mathbf{J}$. A T. Boubée and M. A. Chapman, Mr L. J. Gaylor (University of Waikato), and Mrs M. Lowe and Miss T. Lane. We are grateful to Dr A. G. Hogg (University of Waikato Radiocarbon Dating Laboratory) for rapidly processing C-14 dates and for releasing a previously unpublished date (Wk114, submitted by $\mathrm{Dr} \mathrm{A}$. T. Wilson and $\mathrm{Mr} \mathrm{K}$. Thompson) on the Rukuhia bog. Dr P. C. Froggatt and Messrs G. J. Gosson, K. Palmer, and J. Carter (Victoria University of Wellington) are thanked for their help in obtaining the electron microprobe analyses, and Dr R. Howorth (Victoria University of Wellington) for his useful comments on the manuscript. $\mathrm{Mr} \mathrm{B}$. Davies is particularly thanked for willingly providing access to Lake Maratoto. 


\section{REFERENCES}

Berg, K.; Petersen, I. C. 1956: Studies on the humic, acid Lake Gribsø. Folia Limnologica Scandinavica 8. $273 \mathrm{p}$.

Binford, M. W.; Deevey, E. S.; Crisman, T. L. 1983: Paleolimnology: an historical perspective on lacustrine ecosystems. Annual reviews of ecology and systematics $14: 255-286$.

Birks, H. J. B.; Birks, H. H. 1980: Quaternary paleoecology. London, Edward Arnold. 289 p.

Birrell, K. S.; Pullar, W. A. 1973: Weathering of paleosols in Holocene and late Pleistocene tephras in central North Island, New Zealand. New Zealand journal of geology and geophysics 16: 687-702.

Björck, S.; Håkansson, S. 1982: Radiocarbon dates from Late Weichselian lake sediments in South Sweden as a basis for chronostratigraphic subdivision. Boreas 11: 141-150.

Boubée, J. A. T. 1983: Past and present benthic fauna of Lake Maratoto with special reference to the Chironomidae. Unpublished D.Phil. thesis, University of Waikato Library, Hamilton, New Zealand.

Brugam, R. B. 1984: Holocene paleolimnology. Pp. 208221 in: Wright, H. E. jun. ed. Late-Quaternary environments of the United States. Vol. 2. The Holocene. Minneapolis, University of Minnesota Press.

Burrows, C. J. 1979: A chronology for cool-climate episodes in the Southern Hemisphere $12000-1000$ yr B.P. Palaeogeography, palaeoclimatology, palaeoecology 27 : 287-347.

Cole, J. W.; Nairn, I. A. 1975: Catalogue of the active volcanoes and solfatara fields of New Zealand. International Association of Volcanology and Chemistry of the Earth's interior. Part XXII. 156 p.

Colhoun, E. A.; van de Geer, G.; Mook, W. G. 1982: Stratigraphy, pollen analysis, and paleoclimatic interpretation of Pulbeena Swamp, northwestern Tasmania. Quaternary research 18: 108-126.

Davis, M. B.; Ford, M. S. 1982: Sediment focussing in Mirror Lake, New Hampshire. Limnology and oceanography 27: 137-150.

Deevey, E. S. 1955: Paleolimnology of the upper swamp deposit, Pyramid Valley. Records of the Canterbury Museum (New Zealand) 6: 291-344.

Fleming, C. A. 1979: The geological history of New Zealand and its life. Auckland, Auckland University Press. $141 \mathrm{p}$.

Folk, R. L. 1968: Petrology of sedimentary rocks. Austin, Texas, Hemphill's (The University of Texas). 170 p.

Frey, D. G. 1954: Evidence for the recent enlargement of the "Bay" lakes of North Carolina. Ecology 35: 78-88.

ed. 1969: Symposium on paleolimnology. Mitteilungen der Internationalen vereinigung für Theoretische und Angewandte Limnologie 17. 448 p.

Froggatt, P. C. 1983: Toward a comprehensive Upper Quaternary tephra and ignimbrite stratigraphy in New Zealand using electron microprobe analysis of glass shards. Quaternary research 19:188-200.
Froggatt, P. C.; Gosson, G. J. 1982: Techniques for the preparation of tephra samples for mineral and chemical analysis and radiometric dating. Geology' Department, Victoria University of Wellington publication 23. $12 \mathrm{p}$.

Grange, L. I.; Taylor, N. H.; Sutherland, C. F.; Dixon, J. K.; Hodgson, L.; Seelye, F. T. 1939: Soils and agriculture of part of Waipa County. New Zealand Department of Scientific and Industrial Research bulletin $76.85 \mathrm{p}$.

Harris, W. F. 1963: Paleoecological evidence from pollen and spores. New Zealand Ecological Society proceedings $10: 38-44$.

Heinselman, M. L. 1970: Landscape evolution, peatland types, and the environment in the Lake Agassiz peatlands natural area, Minnesota. Ecological monographs $40: 235-261$.

Hendy, C. H.; Wilson, A. T. 1968: Paleoclimatic data from speleothems. Nature 219:48-51.

Heusser, C. J.; Streeter, S. S. 1980: A temperature and precipitation record of the past 16000 years in southern Chile. Science 210:1345-1347.

Hogg, A. G. 1982: Radiocarbon dating at the University of Waikato, New Zealand. Occasional report 8 . University of Waikato, Department of Earth Sciences. 52 p.

Hogg, A. G.; McCraw, J. D. 1983: Late Quaternary tephras of Coromandel Peninsula, North Island, New Zealand: a mixed peralkaline and calcalkaline tephra sequence. New Zealand journal of geology and geophysics 26: 163-187.

Howorth, R.; Froggatt, P. C.; Robertson, S. M. 1980: Late Quaternary volcanic ash stratigraphy of the Poukawa area, central Hawke's Bay, New Zealand. New Zealand journal of geology and geophysics $23: 487-$ 491.

Hume, T. M.; Sherwood, A. M.; Nelson, C. S. 1975: Alluvial sedimentology of the Upper Pleistocene Hinuera Formation, Hamilton Basin, New Zealand. Journal of the Royal Society of New Zealand 5 $421-462$.

Irwin, J. 1982: Lake Maratoto: Lake Mangakaware bathymetry 1:2000. New Zealand Oceanographic Institute chart, lake series.

Kear, D.; Schofield, J. C. 1978: Geology of the Ngaruawahia Subdivision. New Zealand Geological Survey bulletin $80.168 \mathrm{p}$.

Kennedy, N. M.; Pullar, W. A.; Pain, C. F. 1978: Late Quaternary land surfaces and geomorphic changes in the Rotorua Basin. North Island, New Zealand. New Zealand journal of science 21: 249-264.

Kohn, B. P. 1979: Identification and significance of a late Pleistocene tephra in Canterbury district, South Island, New Zealand. Quaternary research 11:7892.

Lowe, D. J. 1981: Origin and composite nature of late Quaternary airfall deposits, Hamilton Basin, New Zealand. Unpublished M.Sc. thesis, University of Waikato Library, Hamilton, New Zealand.

- 1985: Application of impulse radar to continuous profiling of tephra-bearing lake sediments and peats: an initial evaluation. New Zealand journal of geology and geophysics 28: (this issue). 
Lowe, D. J.; Hogg, A. G. in press: Tephrostratigraphy and chronology of the Kaipo Lagoon, an 11,500 yearold montane peat bog in Urewera National Park, New Zealand. Journal of the Royal Society of New Zealand 16. (1986).

Lowe, D. J.; Hogg, A. G.; Green, J. D.; Boubée, J. A. T. 1980: Stratigraphy and chronology of late Quaternary tephras in Lake Maratoto, Hamilton, New Zealand. New Zealand journal of geology and geophysics 23: 481-485.

Mackereth, F. J. H. 1966: Some chemical observations on post-glacial lake sediments. Philosophical transactions of the Royal Society 250: 165-213.

Mathewes, R. W.; Westgate, J. A. 1980: Bridge River tephra: revised distribution and significance for detecting old carbon errors in radiocarbon dates of limnic sediments in southern British Columbia. Canadian journal of earth sciences 17: 1454-1461.

McCraw, J. D. 1967: The surface features and soil pattern of the Hamilton Basin. Earth science journal 1 : 59-74.

McGlone, M. S. 1983: Holocene pollen diagrams, Lake Rotorua, North Island, New Zealand. Journal of the Royal Society of New Zealand 13: 53-65.

McGlone, M. S.; Topping, W. W. 1977: Aranuian (postglacial) pollen diagrams from the Tongariro region, North Island, New Zealand. New Zealand journal of botany 15:749-760.

1983: Late Quaternary vegetation, Tongariro region, central North Island, New Zealand. New Zealand journal of botany $21: 53-76$.

McGlone, M. S.; Nelson, C. S.; Hume, T. M. 1978: Palynology, age and environmental significance of some peat beds in the Upper Pleistocene Hinuera Formation, South Auckland, New Zealand. Journal of the Royal Society of New Zealand 8: 385-393.

McGlone, M. S.; Nelson, C. S.; Todd, A. J. 1984a: Vegetation history and environmental significance of pre-peat and surficial peat deposits at Ohinewai, Lower Waikato lowland. Journal of the Royal Society of New Zealand 14: 233-244.

McGlone, M. S.; Howorth, R.; Pullar, W. A. 1984b: Late Pleistocene stratigraphy, vegetation and climate of the Bay of Plenty and Gisborne regions, New Zealand. New Zealand journal of geology and geophysics $27: 327-350$.

Moss, B. 1980: Ecology of freshwaters. Oxford, Blackwell Scientific Publications. $332 \mathrm{p}$.

Nairn, I. A. 1980: Source, age, and eruptive mechanisms of Rotorua Ash. New Zealand journal of geology and geophysics 23: 193-207.

Pennington, W. 1981: Records of a lake's life in time: the sediments. Hydrobiologia 79: 197-219.

Pigott, C. D.; Pigott, M. E. 1963: Late-glacial and postglacial deposits at Malham, Yorkshire. New phytologist $62: 317-334$.
Pullar, W. A.; Birrell, K. S. 1973: Age and distribution of late Quaternary pyroclastic and associated cover deposits of the Rotorua and Taupo area, North Island, New Zealand. New Zealand soil survey report 1 .

Pullar, W. A.; Heine, J. C. 1971: Ages, inferred from ${ }^{14} \mathrm{C}$ dates, of some tephra and other deposits from Rotorua, Taupo, Bay of Plenty, Gisborne and Hawke's Bay districts. Proceedings Radiocarbon Users' Conference, Lower Hutt : 117-138.

Pullar, W. A.; Birrell, K. S.; Heine, J. C. 1973: Named tephras and tephra formations occurring in the central North Island, with notes on derived soils and buried paleosols. New Zealand journal of geology and geophysics 16:497-518.

Sarna-Wojcicki, A. M.; Bowman, H. R.; Meyer, C. E.; Russell, P. C.; Woodward, M. J.; McCoy, G.; Rowe, J. J. jun.; Baedecker, P. A.; Asaro, F.; Michael, H. 1984: Chemical analyses, correlations, and ages of Upper Pliocene and Pleistocene ash layers of eastcentral and southern California. U.S. Geological Survey professional paper 1293. 40 p.

Schofield, J. C. 1965: The Hinuera Formation and associated Quaternary events. New Zealand journal of geology and geophysics 8: 772-791.

Stewart, R. B.; Neall, V. E. 1984: Chronology of paleoclimatic change at the end of the last glaciation. Nature 311: 47-48.

Street, F. A.; Grove, A. T. 1979: Global maps of lakelevel fluctuations since $30000 \mathrm{yr}$ B.P. Quaternary research $12: 83-118$.

Topping, W. W. 1973: Tephrostratigraphy and chronology of late Quaternary eruptives from the Tongariro Volcanic Centre, New Zealand. New Zealand journal of geology and geophysics 16:397-423.

Vucetich, C. G.; Howorth, R. 1976a: Proposed definition of the Kawakawa Tephra, the c. 20000 years B.P. marker horizon in the New Zealand region. New Zealand journal of geology and geophysics 19:4350.

1976b: Late Pleistocene tephrostratigraphy in the Taupo district, New Zealand. New Zealand journal of geology and geophysics 19: 51-69.

Vucetich, C. G.; Pullar, W. A. 1969: Stratigraphy and chronology of late Pleistocene volcanic ash beds in central North Island, New Zealand. New Zealand journal of geology and geophysics 12: 784-837.

Walker, D. 1970: Direction and rate in some British postglacial hydroseres. Pp. 117-139 in: Walker, D.; West, R. G. ed. Studies in the vegetational history of the British Isles. Cambridge, University Press.

Wells, B. W.; Boyce, S. G. 1953: Carolina Bays: additional data on their origin, age and history. Journal of the Elisha Mitchell Scientific Society 69: 119-141. 